Ana Teresa Ribeiro Contier

\title{
UM MODELO DE EXTRAÇÃO DE PROPRIEDADES DE TEXTOS USANDO PENSAMENTO NARRATIVO E PARADIGMÁTICO
}

Dissertação de Mestrado apresentada à Escola Politécnica da Universidade de São Paulo para obtenção do Título de Mestre em Engenharia Elétrica

São Paulo

2007 
Ana Teresa Ribeiro Contier

\section{UM MODELO DE EXTRAÇÃO DE PROPRIEDADES DE TEXTOS USANDO PENSAMENTO NARRATIVO E PARADIGMÁTICO}

Dissertação de Mestrado apresentada à Escola Politécnica da Universidade de São Paulo para obtenção do Título de Mestre em Engenharia Elétrica

Área de Concentração:

Sistemas Eletrônicos

Orientador:

Professor Dr. Marcio Lobo Netto

São Paulo

2007 
Este exemplar foi revisado e alterado em relação à versão original, sob responsabilidade única do autor e com a anuência de seu orientador.

São Paulo, de maio de 2007.

Assinatura do autor

Assinatura do orientador

1. FICHA CATALOGRÁFICA

Contier, Ana Teresa Ribeiro

Um modelo de extração de propriedades de textos usando pensamento narrativo e paradigmático / A.T.R. Contier. -- ed.rev. -- São Paulo, 2007.

$73 \mathrm{p}$.

Dissertação (Mestrado) - Escola Politécnica da Universidade de São Paulo. Departamento de Engenharia de Sistemas Eletrônicos.

1.Ciência cognitiva 2.Inteligência artificial simbólica 3.Teoria literária I.Universidade de São Paulo. Escola Politécnica. Departamento de Engenharia de Sistemas Eletrônicos II.t. 


\section{DEDICATÓRIA}

Aos meus pais que sempre estiveram ao meu lado e apoiaram as minhas escolhas. E aos meus amigos queridos, Ana Claudia e Érico Rigorini que me incentivaram a trilhar novos caminhos. 


\section{AGRADECIMENTOS}

Lutar com palavras

é a luta mais vã.

(O Lutador, Drummond)

Escrever é lutar com as palavras até o Sol nascer. É selecionar a palavra que mais convém. É passar horas em frente à página em branco e ver nela a angústia de não tê-la preenchido. Não importa o que escreva: poema, carta de amor, histórias sobre seu cotidiano. Com certeza, alguma vez na sua vida, caro leitor, tivera que entrar nesta luta tão vã. Saiba que esta escritora enfrentou, além desta, outra: a batalha com os algoritmos. Como escolher aqueles os que melhor representariam os conceitos tratados nesta dissertação? Os dados com suas seis faces estavam lançados. Não dava para voltar. Combinar cada face para resultar em uma coerente era o desafio desta escritora. Pesquisa e mais pesquisa, horas e horas de estudo e muita dedicação foram essenciais, mas sem o auxílio de pessoas especiais, caro leitor, esta escritora teria perdido esta batalha.

Agradeço ao meu orientador Prof. Dr. Marcio Lobo Netto, pela ousadia em aceitar o tema deste mestrado, por sua condução, incentivo e dedicação em todo o processo de orientação. Ele, sem dúvida nenhuma, leitor, foi peça fundamental neste trabalho.

Agradeço também aos integrantes do Cognitio, pela troca, carinho e atenção e aos professores e colegas de pós-graduação que me acolheram e me ajudaram nesta jornada. Em particular Bruno Barberi Gnecco, intérprete humanês/engeinheirês, que, com muita paciência, me auxiliou na programação e execução do programa. 
All people dream, but not equally. Those who dream by night in the dusty recesses of their mind, Wake in the morning to find that it was vanity.

But the dreamers of the day are dangerous people, For they dream their dreams with open eyes, And make them come true.

(Dreams - D.H Lawrence) 


\section{RESUMO}

Este trabalho procura entender como 0 homem formula seus pensamentos e com eles age no mundo. Não nos cabe esgotar tal assunto e sim, discuti-lo e apresentar um modelo de como este processo possivelmente ocorre. Para tanto foi feita uma releitura dos modos de pensamento estudados pelo psicólogo Jerome Bruner na década de 80: pensamento narrativo e paradigmático. Para o psicólogo, estes pensamentos são antagônicos; entretanto, nesta dissertação, será mostrado que estes dois pensamentos podem estar interligados. $O$ pensamento narrativo é entendido aqui como uma narrativa criada pelo homem, baseada em sua memória e na sua interação com a sociedade e o pensamento paradigmático, como proposições derivadas da história narrada. O software "Aristóteles" foi desenvolvido com o objetivo de representar a interação entre o pensamento narrativo e o paradigmático. Esta representação é o primeiro passo para se discutir como, supostamente, o ser humano pensa. Não há a intenção em simular a mente humana, mas demonstrar que o estudo da mente humana pode servir de subsídios para criação de softwares. Assim, além da teoria de Bruner, o programa foi baseado na pesquisa sobre pensamento e palavra de Vygotsky e teoria dos gêneros de Bakhtin. Para a implementação do "Aristóteles" foram usadas regras da Inteligência Artificial Simbólica (IAS) escritas em linguagem orientada a objetos (Java).

Palavras-chave: Pensamento. Narrativa. Proposições. Gêneros. Inteligência Artificial. 


\begin{abstract}
This work seeks to understand how man formulates his thoughts and use them to act in the world. It is not our purpose to exhaust this subject, but to discuss it and present a model of how this process might possibly occur. For this we made a new lecture of the thinking modes studied by the psychologist Jerome Bruner in the 1980s: narrative thinking and paradigmatic thinking. To Bruner, these modes of thinking are opposites; however, in this work, we will show that these two modes may be interconnected. Narrative thinking is understood here as a narrative created by man, based on his memory and his interaction with society, and the paradigmatic thinking as a propositions derived from the narrated story. The software Aristoteles was developed, as part of this work, with the goal of representing the interaction between narrative and paradigmatic thinking. This representation is the first step to discuss how man supposedly thinks. There is no intention to simulate the human mind, but to show that its study might be useful to create software. Therefore, besides Bruner's theory, the program was based on a research of thinking, the writing of Vygotsky and Bakhtin's genre theory. To implement Aristoteles we used rules of Symbolic Artificial Intelligence written in an object oriented language (Java).
\end{abstract}

Keywords: Thinking. Narrative. Propositions. Genres. Artificial intelligence. 
Abaixo descrevemos a notação utilizada nesta dissertação:

A) Termos em inglês ou em outra língua onde não se encontrou tradução direta ao português até o momento da escrita da dissertação serão apresentados em itálico.

Exemplo: frames

B) Termos em inglês traduzidos serão apresentados à direita do termo em português em itálico e entre parênteses.

Exemplo: Hipótese de Sistema de Símbolos Físicos (Physical Symbol System Hypothesis) 


\section{LISTA DE ILUSTRAÇÕES}

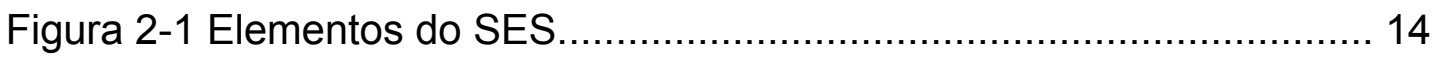

Figura 2-2 Elementos do SEC. ....................................................... 15

Figura 4-1 Interface gráfica "Aristóteles"............................................. 32

Figura 4-2 Diagrama UML "Aristóteles". .............................................. 38

Figura 4-3 Diagrama UML "Aristóteles" (continuação).............................. 39

Figura 4-4 Encontro entre amigos "The Sims" ......................................... 54

Figura 4-5 Avatar "Second Life" ......................................................... 55

Figura 5-1 Resultado da história 1.................................................. 59

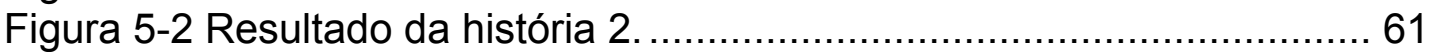

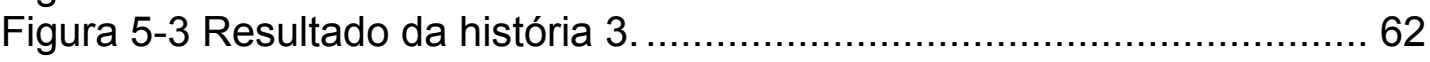

Figura 5-4 Resultado da história 4 .................................................... 63 


\section{LISTA DE TABELAS}

Tabela 3-1 Comparação entre os conceitos de Bruner e os aplicados em

"Aristóteles".....

Tabela 4-1 Regras sintáticas do campo sujeito. ……………………….... 34

Tabela 4-2 Regras sintáticas do campo verbo.......................................... 34

Tabela 4-3 Regras sintáticas dos campos objeto 1 e objeto 2 ...................... 34

Tabela 4-4 Regras sintáticas do campo advérbio de tempo........................ 35

Tabela 4-5 Regras sintáticas do campo advérbio de lugar.......................... 35

Tabela 4-6 Palavras-chave e seus pesos. ............................................. 42

Tabela 4-7 Sentenças da "mocinha" e seus valores.................................. 43

Tabela 4-8 Sentenças do "mocinho" e seus valores.................................... 43

Tabela 4-9 Sentenças da "conquista" e seus valores.................................. 44

Tabela 4-10 Sentenças do "morto". ........................................................... 46

Tabela 4-11 Sentenças do "assassino" e seus valores. ............................... 46 


\section{LISTA DE ABREVIATURAS E SIGLAS}

$\begin{array}{ll}\text { DPCOL } & \text { Decompositional Partial - Order Causal - Link Planner } \\ \text { IAC } & \text { Inteligência Artificial Conexionista } \\ \text { IAS } & \text { Inteligência Artificial Simbólica } \\ \mathrm{NI} & \text { Narrative Intelligence } \\ \text { PSSH } & \text { Hipótese de Sistema de Símbolos Físicos (Physical Symbol } \\ & \text { System Hypothesis) } \\ \text { SE } & \text { Sistema Especialista } \\ \text { SEC } & \text { Sistema Especialista Conexionista } \\ \text { SES } & \text { Sistema Especialista Simbólico } \\ \text { UML } & \text { Linguagem de Modelagem Unificada (Unified Modeling } \\ & \text { Language) }\end{array}$




\section{SUMÁRIO}

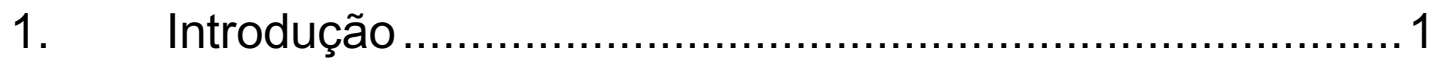

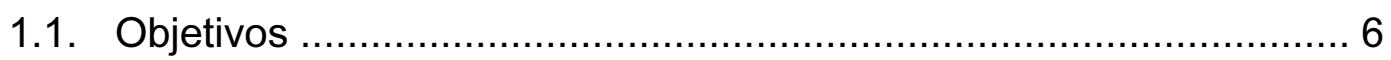

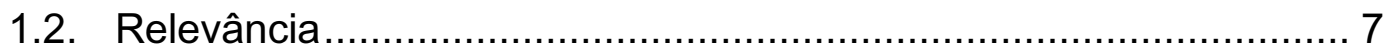

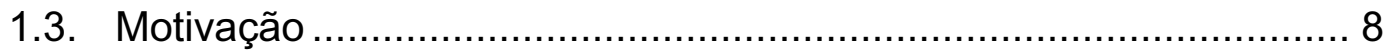

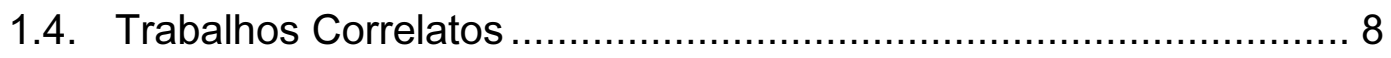

1.5. Estrutura da Dissertação ............................................................ 9

2. Pensamento: Diversas Abordagens ............................ 10

2.1. Pensamento Humano: Abordagem Feita pela Inteligência Artificial Simbólica

2.2. Pensamento Humano: Abordagem Feita pela Inteligência Artificial

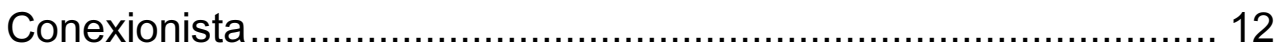

2.3. Sistemas Especialistas (SE) .................................................. 13

2.3.1. Sistemas Especialistas Simbólicos (SES) ........................... 14

2.3.2. Sistema Especialista Conexionista (SEC) ........................... 15

2.4. Críticas à Inteligência Artificial .................................................... 16

2.5. Pensamento Conforme Jerome Bruner ...................................... 17

2.5.1. Pensamento Paradigmático …………................................ 18

2.5.2. Pensamento Narrativo ..................................................... 19

3. Aristóteles: Conceitos Norteadores ............................. 22

3.1. Gênero Romântico: Folhetim .................................................... 24

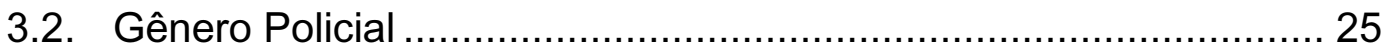

3.3. Comparação entre os Conceitos de Bruner e os Conceitos Representados pelo Modelo Aristóteles ....................................... 26

3.4. Contribuições e potencialidades................................................. 28

4. $\quad$ Aristóteles: Implementação...........................................31 


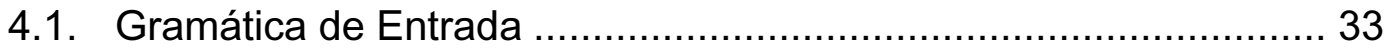

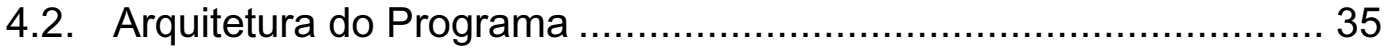

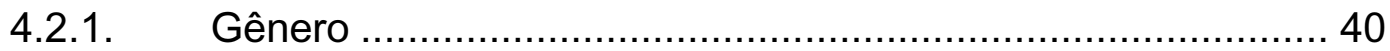

4.2.2. Pensamento Paradigmático ............................................ 47

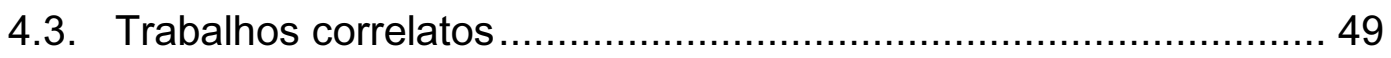

4.3.1. Trabalhos do grupo Cognitio ……...................................... 49

4.3.2. Criação de Narrativas Inteligentes: Liquid Narrative Group e

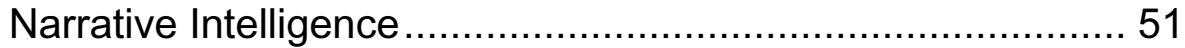

4.3.3. Jogos de Simulação do Cotidiano: The Sims e Second Life .. 53

5. Testes e Resultados ................................................... 57

6. Considerações Finais e Trabalhos Futuros .....................65

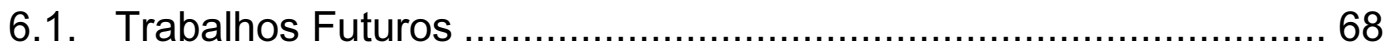

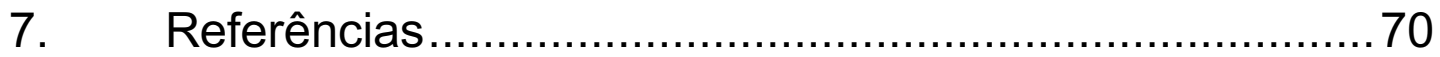




\section{Introdução}

A Ciência Cognitiva é um campo do saber relativamente novo. Surgiu em meados da década de 1950, com objetivo de estudar a mente e toda a sua representação computacional. Por ser um assunto complexo, exige esforço de diversas áreas do saber, tais como: Lingüística, Filosofia, Neurociência e Inteligência Artificial. Para Thagard (1998, p.2) "o principal objetivo da Ciência Cognitiva é explicar como as pessoas desenvolvem vários tipos de pensamento". Já Posner (1998, p.1) enfatiza a inteligência em sua definição: "Ciência Cognitiva é o estudo da inteligência e de sistemas inteligentes com particular referência ao comportamento inteligente como computacional". Começa-se a perceber como este ramo é complicado: cada autor aborda esta ciência de forma diferente, mas não antagônica.

Thagard (1998) faz um panorama da Ciência Cognitiva. De acordo com ele, por volta de 1956, o campo intelectual mudou drasticamente. George Miller resumiu numerosos estudos que mostraram como a capacidade de pensamento humano é limitada, com a memória em curto prazo restrita à sete itens. Pioneiros como John McCarthy, Marvin Minsky, Allen Newell e Herbert Simon estavam fundando o campo da Inteligência Artificial. E mais, Noam Chomsky $(1957,1959)$ rejeitou o behaviorismo, que assumia a linguagem como um hábito aprendido e propôs explicar a habilidade humana para entender a linguagem em termos de gramática mental com regras. Estes seis pensadores podem ser vistos como os fundadores da ciência cognitiva.

Posner (1998) também apresenta a história da ciência cognitiva, entendendo-a como a conexão entre diferentes teorias de representação mental. McCarthy se tornou um dos líderes no ramo da Inteligência Artificial baseada na lógica formal. Durante os anos 60, Newell e Simon mostraram o poder das regras de aspectos da inteligência humana. Durante os anos 70 , 
Minsky propôs o conceito de frames como a forma central de representação do conhecimento. Nos anos 80, houve o crescimento das teorias conexionistas de representação mental e processamento modelado em redes neurais. Cada uma destas abordagens contribuiu para um melhor entendimento da mente.

Ao observar este breve histórico, pode-se definir Ciência Cognitiva como o estudo dos diversos processos mentais, sejam eles, aprendizado, pensamento ou inteligência, que podem ser representados computacionalmente. Esta dissertação está focada no pensamento. Sabe-se que as funções mentais atuam em conjunto. Aqui, elas não serão discutidas, assumindo-se que atenção, aprendizado, memória e percepção estejam inseridas no processo de criação e armazenamento do pensamento. Mas o que é o pensamento?

Das várias definições feitas, duas são bem claras. Para Jung (1947, p.542), "o pensamento é uma função psicológica racional que estabelece relações de ordem comportamental entre conteúdos representativos, através da utilização de categorias de verdadeiro ou falso, ou como certo ou errado". Outra definição que pode ser complementar a esta é de Jolivet (1972, p.43): "pensamento é a capacidade que tem o ser humano de conhecer em que consistem as coisas e as relações que elas têm entre si". Destes dois conceitos, estabelece-se a primeira premissa:

Premissa a) pensamento é racional, uma forma de conhecer, entender o universo e organizá-lo em categorias.

Pode-se perguntar se o pensamento é realizado por palavras, sons, imagens visuais etc. Este artigo toma por base os estudos da fala humana realizados por Vygotsky e Luria (1994) para responder esta pergunta. Os pesquisadores mostram como a fala serve para resolver problemas e como ela é externalização de uma fala interna. Eles fizeram experiências e observaram que a criança, ao se esforçar para resolver os problemas, fala. 
Esta fala concomitante com a ação ocorre espontaneamente, quase sem interrupção até o final da atividade proposta. Ela se torna mais persistente à medida que as dificuldades aumentam. Assim os estudiosos argumentam que é necessário e natural à criança falar enquanto resolve um problema, não apenas para contar o que está fazendo, mas, principalmente, porque está externando seu pensamento (sua fala interna). Sendo assim: "a criança resolve uma tarefa prática com a ajuda não só dos olhos e das mãos como também da fala" (VYGOTSKY; LURIA, 1994). Desta forma, a fala serve para criar uma ponte entre o mundo interno e o mundo externo da criança e mais, por meio da fala ela cria e organiza representações do mundo e consegue manipular diversos conceitos.

Deriva-se daí a segunda premissa:

Premissa b) pensamento lingüístico é a voz interna, que ajuda organizar as idéias do ser humano através do uso de palavras.

Este trabalho se baseia em duas formas de pensamento: o narrativo e o paradigmático. Estes modos foram pesquisados por Bruner na década de 80 e servem como ponto de partida para esta dissertação. Jerome Bruner é professor pesquisador de psicologia da Universidade de Nova York. A linha de pesquisa de Bruner sofre influências do psicólogo russo Vygotsky e do filósofo Nelson Goodman. De Vygotsky, Bruner aproveita a idéia de estrutura "andaime", isto é, a teoria que propõe que as crianças, ao se desenvolverem, utilizam a linguagem e histórias dos adultos para construírem suas próprias linguagens e histórias. Da parte de Goodman, é absorvida a noção de que nenhum "mundo" criado e vivido pelo homem é mais "real" do que outro e que nenhum deve ser considerado como o único mundo real. Seu principal livro é Realidade Mental, Mundos Possíveis 
publicado em 1986, uma coletânea que reúne vários ensaios em torno destas duas inspirações marcantes. Dividido em três partes, o livro trata, na primeira, de discutir as questões relacionadas aos dois tipos naturais de modos de pensamento, o narrativo e o paradigmático, dando-se maior ênfase à análise das histórias literárias. Na segunda parte, as presenças de Vygotsky e Goodman são mais explícitas. Nela, são feitas considerações sobre a formação do "eu", através da linguagem e sua construção da realidade. Na última parte, discutem-se as implicações entre as teorias pedagógicas, que abordam o processo de aprendizagem e as teorias do desenvolvimento intelectual, nos moldes de Piaget. Bruner examina estes assuntos sempre tomando a literatura como um instrumento de liberdade, leveza e imaginação.

No capítulo, Dois Modos de Pensamento, Bruner aponta as distinções entre o modo de pensar narrativo e o lógico-científico. O autor defende a tese de que esses dois modos de funcionamento cognitivo constroem realidades, ordenando a experiência cada um da sua forma. Apesar disso, ambos discursos seriam complementares entre si, sem que um se reduza ao outro. O pensamento lógico-científico, que Bruner chama de paradigmático, se associa ao discurso teórico e ao logos, ou seja, são utilizados argumentos para estabelecer "o ideal de um sistema formal e matemático de descrição e explicação" (BRUNER, 2002, p. 13). Para isso, um cientista ou filósofo procura criar categorias ou conceitos, relacionando-os uns com os outros até formar um sistema geral baseado em hipóteses fundamentadas, isto é, que podem ser demonstradas como verdadeiras. Por sua vez, a narrativa, mítica ou literária, aborda a maneira pela qual as intenções humanas se comportam nas mais diversas situações. Nesse sentido, as histórias, que são criadas, traçam relatos de ações humanas em circunstâncias de experiência localizadas num tempo e espaço definidos, enquanto o discurso teórico tenta ir além dos fatos particulares, visando formulações de princípios gerais e abstratos. 
As realidades narrativizadas, eu suspeito, são demasiadamente onipresentes, sua construção é demasiadamente habitual ou automática para ser acessível à fácil inspeção. Vivemos em um mar de histórias, e como os peixes que (de acordo com o provérbio) são os últimos a enxergar a água, temos nossas próprias dificuldades em compreender o que significa nadar em histórias. Não que não tenhamos competência em criar nossos relatos narrativos da realidade - longe disso-, somos, isso sim, demasiadamente versados. Nosso problema, ao contrário, é atingir uma consciência do que fazemos facilmente de forma tão automática, o antigo problema da prise de conscience. (BRUNER, 2001, p.140)

Para Bruner (2002) estes dois tipos de pensamentos funcionam de forma diferente no ordenamento da experiência pessoal do indivíduo e na construção da realidade. Para ele, os dois são complementares, porém, irredutíveis como fora explicado anteriormente. Abaixo, o resumo das principais características de cada um:

Cada uma das maneiras de conhecimento tem princípios operativos próprios e seus próprios critérios de boa formação. (...) ambos podem ser usados como meio de convencer o outro. Não obstante, do que eles convencem é fundamentalmente diferente: os argumentos convencem alguém de sua veracidade, as histórias de sua semelhança com a vida. O primeiro comprova através de um possível apelo a procedimentos para estabelecer provas formais e empíricas. O outro estabelece não a verdade, mas a verossimilhança. (BRUNER, 2002, p.12).

Levando-se em conta os dois tipos de pensamento, parte-se para terceira premissa:

Premissa c) pensamento lingüístico pode ser expresso através de uma narrativa e/ou proposição.

É importante ressaltar que devido à complexidade do assunto pensamento, não se pode abarcá-lo em sua totalidade. Ao longo do texto, 
será esclarecido como o tema "pensamento" foi trabalhado e como os conceitos de Bruner foram reavaliados. Pode-se adiantar que a principal diferença entre este trabalho e o de Bruner é relacionar o pensamento narrativo à esfera do cotidiano e demonstrar como dele é possível extrair proposições. Conforme Calvin (2004, p.46):

As capacidades humanas de planejamento podem vir de nosso talento para construirmos narrativas. Podemos tomar emprestadas as estruturas mentais da sintaxe para avaliar as combinações de ações possíveis. Em certo grau, fazemos isso conversando em silêncio conosco, criando narrativas a partir do que poderia acontecer e aplicando regras sintáticas de combinação para considerar um cenário, improvável, possível ou provável. As narrativas também são um dos maiores fundamentos das escolhas éticas: imaginamos um curso de ação e seus efeitos sobre os outros, e então decidimos tomá-lo ou não.

Sendo assim, a narrativa, além de ser fundamental para construção da cultura e da identidade do ser humano, como prega Bruner, serve para decidir sobre algo, pois, o homem ao criar cenários de eventos possíveis e imaginar as diversas conseqüências de um ato, está decidindo qual atitude tomará. Este trabalho argumenta que é possível derivar proposições das narrativas criadas e que elas possivelmente norteariam a tomada de decisão ${ }^{1}$ do indivíduo. O software desenvolvido, "Aristóteles" ${ }^{2}$, se baseia neste argumento e serve para extrair proposições de narrativas. Para isto foram reavaliados e simplificados o conceito de gênero de Bakhtin, a concepção de fala interna de Vygotsky e, principalmente, os tipos de pensamento de Bruner

\subsection{Objetivos}

O objetivo geral deste trabalho é contribuir para uma discussão sobre alguns aspectos relacionados a como o ser humano possivelmente pensa.

\footnotetext{
${ }^{1}$ Neste trabalho não se falará sobre a Teoria da Tomada de Decisão. Aqui o termo é utilizado para identificar qualquer ação do ser humano resultante do seu pensamento.

2 "Aristóteles" é o nome do programa desenvolvido nesta dissertação. A escolha dele é uma homenagem ao filósofo Aristóteles que escreveu importante obra Poética. Muitos estudiosos a consideram o marco dos estudos literários.
} 
Destacam-se os seguintes objetivos específicos deste trabalho:

- Mostrar como o pensamento narrativo e o paradigmático atuam de forma conjunta;

- Analisar e ampliar as definições de pensamento paradigmático e narrativo feitas por Bruner (1986);

- Criar um software em que proposições sejam extraídas de narrativas.

\subsection{Relevância}

Uma abordagem mais ampla sobre o pensamento, levando-se em consideração sua característica narrativa, é fundamental para compreender a mente humana. Ao mostrar como o raciocínio atua em conjunto com estruturas narrativas, se estabelecem relações com outras áreas, a saber:

- Desenvolvimento de personagens virtuais: jogos eletrônicos (e games) podem possuir dois cenários, um relativo ao ambiente do jogo e outro à mente da personagem, de onde suas decisões podem ser derivadas, em conformidade com uma narrativa interna criada pelo personagem.

- Terapias: traumas podem ser estudados baseados na narrativa contada pelo paciente. O psicólogo pode ajudá-lo em seu problema se conseguir derivar das histórias proposições que auxiliarão seu cliente a resolver seus problemas.

- Educação: o conhecimento pode ser transmitido recorrendo ao sistema interno de narrativa do aluno.

- Ensino de línguas: o software "Aristóteles" pode ser adaptado para ensinar coerência e coesão em textos. 


\subsection{Motivação}

Estudo da mente é um grande e intrigante desafio. Sua complexidade exige o envolvimento de várias áreas do saber, as quais foram citadas anteriormente. Pensando nisso, o Prof Dr. Henrique Del Nero iniciou em 1990 o grupo de pesquisa em Ciência Cognitiva que esteve até 1997 no Instituto de Estudos Avançados da USP (IEA/USP). Em 1998 este grupo se mudou para Escola Politécnica, onde se encontra até hoje com o nome de Cognitio, Núcleo de Apoio à Pesquisa de Ciências Cognitivas da Universidade de São Paulo (NAP-CC / USP). Ao promover encontros semanais, numa atividade de caráter intelectual e interdisciplinar, o Cognitio possibilita a troca de conhecimento entre seus membros. Nestas reuniões surgiu o tema "Pensamento" e uma discussão sobre agentes e narrativas emergentes. Percebeu-se, assim, que havia um campo muito fértil a ser estudado. Desta forma, iniciou-se a pesquisa que resultou nesta dissertação.

\subsection{Trabalhos Correlatos}

Este trabalho está relacionado ao grupo Cognitio e com trabalhos de componentes deste grupo:

- Dissertação de Mestrado de Marcos Antonio Cavalhieri defendida em 2006: Modelo de Comportamento baseado em Crenças e Teoria de Bayes para simulações em Vida Artificial. Este trabalho apresenta uma série de humanos que estão em um ambiente de "incertezas" e, portanto, usam a Teoria de Bayes para tomarem suas decisões e atuarem neste ambiente;

- Tese de Doutorado de Nilton Terra a ser defendida em 2007: Mastermind: uma abordagem para extração de algoritmos de raciocínio lógico humano. Esta tese em andamento trata de possíveis formas de reconhecimento e extração de procedimentos desenvolvidos para se resolver um jogo. Neste sentido procura 
estabelecer mecanismos de identificação de processos de raciocínio humano.

Não foi encontrado na literatura trabalho com semelhante abordagem, porém, há alguns que, de certa forma, estabelecem relações com este, a saber:

- Grupos como o Narrative Intelligence (MIT) e o Liquid Narrative (Universidade da Carolina do Norte): desenvolvem programas para simulação de narrativas coerentes;

- Jogos que simulam a vida cotidiana como The Sims e Second Life: preocupados em representar o dia-a-dia do ser humano através de narrativas interativas;

Estes trabalhos serão explicados no Capítulo 4 desta dissertação.

\subsection{Estrutura da Dissertação}

Esta dissertação de mestrado encontra-se dividida da seguinte maneira:

- Capítulo 1: Introdução, levantamento do problema e do objeto de estudo.

- Capítulo 2: Conceituação teórica, discussão e crítica de modelos de Inteligência Artificial Simbólica e Conexionista. Apresentação dos conceitos de pensamento narrativo e paradigmático de Bruner (1986).

- Capítulo 3: Explicação de como os conceitos de Bruner foram abordados no Aristóteles. Contribuições e potencialidades desta dissertação.

- Capítulo 4: Implementação do modelo Aristóteles, descrição dos elementos fundamentais. Trabalhos correlatos e comparação deles com o Aristóteles.

- Capítulo 5: Testes, resultados obtidos e sua análise.

- Capítulo 6: Conclusão e trabalhos futuros.

- Referências. 


\section{Pensamento: Diversas Abordagens}

"As Ciências da Cognição surgiram a partir do movimento interdisciplinar que reuniu cientistas de áreas como psicologia cognitiva, lingüística, neurociências, epistemologia, inteligência artificial e antropologia". (ROSA, 1996, p.44). Seu objeto de estudo é a mente e suas funções. Ao se representar a mente através de programas computacionais, estabelece-se uma proximidade entre mente e computador, proximidade esta funcional e não estrutural. Considera-se que o computador possa desempenhar as mesmas funções do cérebro humano, mesmo não possuindo a mesma forma, não há um isomorfismo entre o hardware da máquina e o sistema nervoso, há semelhanças nas características de organização da informação. Tem-se então um problema: como representar as funções mentais?

Para Dupuy (1995), o melhor modelo da mente seria aquele que é capaz de simular a capacidade de representação mental. Para ele isso só é possível se houver associação do estudo da filosofia da mente aos métodos científicos. Muitos cientistas defendem que através da Inteligência Artificial (IA) seja possível a representação da mente. A seguir será mostrado o quanto esta afirmação procede ou não. Para tal será apresentado um panorama da Inteligência Artificial, sua contribuição para Ciência Cognitiva e vice-versa e suas limitações. Depois será apresentado um resumo da teoria de Bruner. No capítulo 3 será mostrado como os conceitos de pensamento narrativo e paradigmático foram adaptados para o desenvolvimento do software "Aristóteles" e como a Inteligência Artificial contribuiu para sua construção. E por fim, o levantamento de trabalhos correlatos e sua comparação com "Aristóteles". 


\subsection{Pensamento Humano: Abordagem Feita pela Inteligência Artificial Simbólica}

Por volta dos anos 50 , surgiram programas computacionais capazes de provar teoremas. Estes se tornaram a base da primeira inteligência artificial, chamada de simbólica. Possui este nome exatamente por lidar com símbolos que seguem regras lógicas. Conforme Rosa (1996), a Inteligência Artificial Simbólica (IAS) faz o uso da lógica como um conjunto de regras que serviria à explicação do funcionamento cerebral, tais como eram aplicadas nos programas. Há a ênfase na representação como aspecto básico da cognição, o que pressupunha a existência de um mundo exterior independente do sujeito que o conhecia e o representava para si. As regras lógicas precisavam ser aplicadas seqüencialmente. O sistema lógicocomputacional utilizava os estados verdadeiro/ falso. De acordo com Del Nero (1997 p. 32) "define-se a mente como um locus de representação, onde os termos mentais (agora símbolos) são manipulados através de regras precisas, algoritmo-computacionais, baseadas no cálculo lógico de predicados." Sendo assim, o pensamento para IAS pode ser representado pela lógica, mais adiante, Del Nero (1997, p 32) fala a respeito:

O pensamento, e sobretudo sua variedade inteligente, será o resultado desse processo de manipulação de símbolos através de regras claras (algoritmos), construindo cadeias de inferência. Esse tipo de modelo é chamado de inteligência artificial simbólica (IAS). Note-se que há uma presunção de que símbolos sejam entidades mentais (portanto, a semântica é mental) e que fundar uma ciência formal do pensamento (ou da cognição e por conseqüência da mente) significa descobrir-lhe as leis lógicas de conexão e inferência - leis do pensamento. A sintaxe é baseada em regras lógicas, por excelência mentais também. (Del Nero, 1997, p.32)

Segundo Paul Churchland (1998, p.161) a meta da Inteligência Artificial (IA) é "criar dispositivos inteligentes". O autor levanta alguns casos como o jogo da velha e de xadrez, em que a máquina seja capaz de jogar, avaliando a situação inicial e criando, por exemplo, a árvore de jogo, que "consiste em todas as possibilidades de jogada" (CHURCHLAND, 1998, p.174). O computador varre cada um desses ramos e avalia se há chance de 
vitória. A cada passo do jogador, a máquina re-avalia seu próximo lance. Assim, a máquina "programada tem uma meta (vencer ou pelo menos empatar), uma gama de respostas possíveis para cada uma das circunstâncias nas quais ela pode se encontrar e um procedimento para resolver, a cada estágio, o problema de qual dessas respostas é a mais apropriada para atingir essa meta". (CHURCHLAND, 1998, p. 177).

Conforme Touretzky e Pomerleau (1994) a IAS se apóia na Hipótese de Sistema de Símbolos Físicos (Physical Symbol System Hypothesis), que admite: para criar inteligência a condição necessária e suficiente é que existam símbolos, estruturas de símbolos e regras que os manipulem. Os seguidores do Physical Symbol System Hypothesis (PSSH) advogam, desta forma, que o cérebro humano e demais entidades que possuem inteligência, não fazem mais que manipular símbolos para gerar inteligência. Assim o cérebro dos seres inteligentes, em última análise, não faz mais que processar símbolos (armazenando-os, modificando-os e gerando outros.). Todo o conhecimento é oriundo do processamento desta matéria-prima.

\subsection{Pensamento Humano: Abordagem Feita pela Inteligência Artificial Conexionista}

Rosa (1996) afirma que um modelo baseado somente na lógica para explicar uma atividade inteligente, a Inteligência Artificial Simbólica (IAS), não seria suficiente, ainda mais se for levado em consideração o funcionamento dos neurônios. Surge, então, a Inteligência Artificial Conexionista (IAC), apoiada nos estudos de neurociência.

Dazzi (1999) afirma que as primeiras informações mencionadas sobre a neuro computação datam de 1943, em artigos de McCulloch e Pitts. Eles sugeriram a construção de uma máquina baseada ou inspirada no cérebro humano. Em 1949, Donald Hebb defendia que o condicionamento psicológico clássico estava presente em qualquer parte do sistema nervoso dos animais, pelo fato de que esta é uma propriedade de neurônios individuais. Suas idéias não eram completamente novas, mas Hebb foi o 
primeiro a propor uma lei de aprendizagem especifica para as sinapses dos neurônios. Este primeiro passo serviu de inspiração para que muitos outros pesquisadores perseguissem a mesma idéia.

Queiroz (1999) afirma que somente em 1958 quando Frank Rosenblatt e Charles Wightman criaram o Perceptron surgiu o conceito de aprendizado em Redes Neurais $\mathrm{O}$ autor resume a topologia do Perceptron:

A topologia. original descrita por Rosenblatt era composta por unidades de entrada (retina), por um nível intermediário formado pelas unidades de associação e por um nível de saída formado pelas unidades de resposta. Embora esta topologia original possua três níveis, ela é conhecida como perceptron de uma única camada, já que somente o nível de saída (unidades de resposta) possui propriedades adaptativas. (Queiroz, 1999, p.14)

Conforme Queiroz (1999) o Perceptron causou grande euforia no meio acadêmico. Todavia, Minsky e Papert fizeram muitas críticas à sua capacidade computacional. Isso ocasionou um desinteresse da comunidade científica pelo estudo das Redes Neurais. Somente no início da década de 80 houve um despertar novamente para esta área com a primeira conferência sobre o assunto, IEEE International Conference on Neural Networks e a formação da International Neural Networks Society (INNS).

De maneira geral, pode-se dizer que o modelo de IAC leva em conta as redes criadas entre os neurônios. Rosa (1996) resume assim:

Cada neurônio conectado - nó da rede - é caracterizado por uma variável que representa seu nível de ativação e por uma constante que representa seu limiar. Quando a ativação de um nó ultrapassa seu limiar, ela se propaga para outros nós de acordo com as ligações existentes, podendo os pesos das conexões ser positivos ou negativos. $O$ estado da rede num determinado instante é dado pela configuração das ativações nesse instante e pelos pesos das conexões. (ROSA, 1996, p. 65)

\subsection{Sistemas Especialistas (SE)}

Sistemas Especialistas (SE) são assim chamados porque são sistemas computacionais que devem se comportar como um "especialista" em determinado assunto. Conforme Dazzi (1999) há dois tipos de SE: 
Sistemas Especialistas Simbólicos (SES) e Sistemas Especialistas Conexionistas (SEC).

\subsubsection{Sistemas Especialistas Simbólicos (SES)}

Dazzi (1999) esquematiza da seguinte forma o SES:

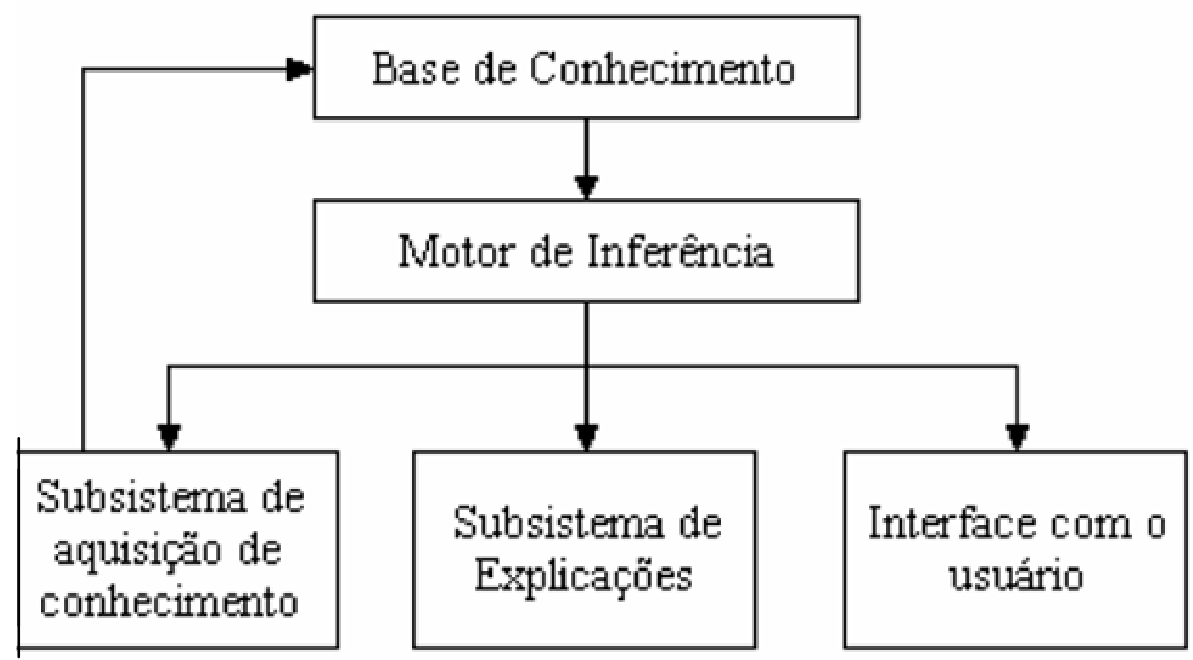

Figura 3-1 Elementos do SES.

Fonte: Dazzi (1999, p.58)

Para o autor o SES é formado por:

- Base de conhecimento: contém as regras que o especialista humano utiliza. Como está separada do motor de inferência fica mais fácil alterá-la, acrescentando ou excluindo dados.

- Motor de inferência: mecanismo que gera novos conhecimentos: infere dos existentes, modifica-os ou os absorve.

- Subsistema de aquisição de conhecimento: deve introduzir novos conhecimentos, alterar ou eliminar os antigos. Responsável pela movimentação das regras na base de conhecimento. 
- Subsistema de explicações: responsável por explicar quais regras o SES usou para chegar a determinado resultado. Isso é importante, caso o usuário discorde da resposta dada.

- Interface com usuário: é o meio de comunicação entre o SES e o usuário. Ela apresenta as entradas e saídas do SES.

De acordo com Bittencourt (1995), o MYCIN foi um dos primeiros SES. Seu objetivo é diagnosticar e indicar terapias para doenças infecciosas. A base de conhecimento possui 450 regras, permitindo diagnosticar e prescrever tratamento para: infecção no sangue, meningite e cistite infecciosa.

\subsubsection{Sistema Especialista Conexionista (SEC)}

A figura 2-2 ilustra os principais elementos do SEC, a saber:

- Base de conhecimento: formada pelos exemplos usados para o treinamento da rede.

- Motor de inferência: recebe as entradas provenientes da interface com o usuário, interage e retorna a resposta.

- Interface com o usuário: meio de comunicação entre o SEC e o usuário.

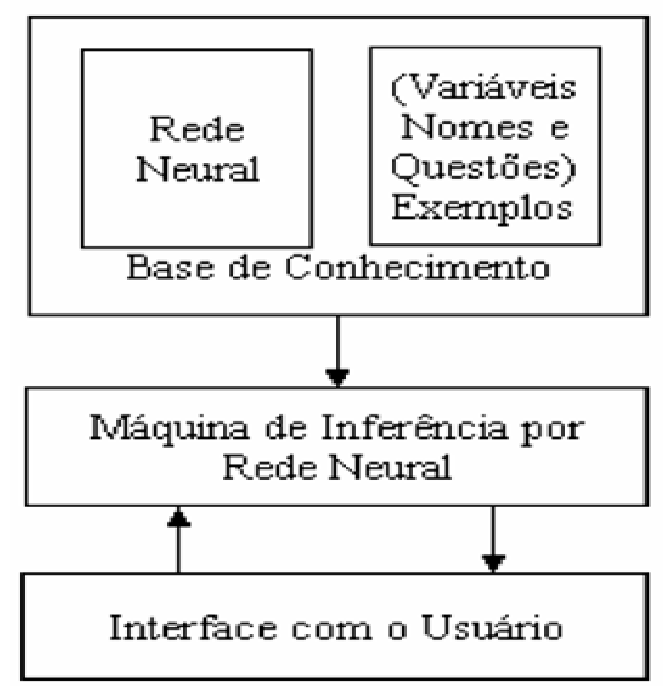

Figura 3-2 Elementos do SEC.

Fonte: Dazzi (1999, p.59) 
Para Dazzi (1999) a escolha entre o SES e o SEC deve levar em conta as características de cada sistema e qual o resultado que se quer atingir. Para o autor, o SEC é indicado em casos em que o "domínio do problema não está bem definido, quando existem muitas exceções as regras, de forma que não se consiga definir com precisão as regras para extração do conhecimento" (DAZZI, 1999, p. 56). Sendo assim, a natureza do problema define qual o melhor método para sua resolução.

\subsection{Críticas à Inteligência Artificial}

Teixeira (1998) enfoca a IA sob o prisma da Ciência Cognitiva. Ele fala sobre as críticas recebidas e as limitações da IAS e IAC.

Ele levanta três principais críticas feitas ao IAS. São elas:

- Dreyfus critica a possibilidade de uma simulação mecânica da mente humana, já que para ele existem características não programáveis na linguagem e no comportamento humano.

- Searle sugere o experimento "quarto chinês": uma pessoa, que não conhece chinês, deve entender sentenças desta língua somente usando um dicionário. Ele se vale deste exemplo para explicar que não é possível haver semântica somente se manipulando símbolos como faz IAS.

- Penrose afirma que há processos mentais não algorítmicos e, portanto, não computáveis.

A IAC também sofre críticas, que Teixeira (1998) expõe:

- Tanto Fodor e Pylyshyn argumentam que IAC não dá conta de modelar a mente humana, pois, sua unidade básica não é formada por símbolos e não possui regras sintáticas. Eles acreditam que as representações mentais só possam ser realizadas se houver sintaxe. 
Churchland (1998) também faz suas críticas. Para o autor, tanto a IAS quanto a IAC ainda não conseguiram resolver problema da representação semântica.

Mesmo com as limitações da IA, esta dissertação argumenta que a relação entre IA e Ciência Cognitiva ainda é muito frutífera. Já que o estudo da mente pode dar subsídios teóricos para construção de softwares mais inteligentes e IA pode servir de ferramenta para simular estados mentais.

\subsection{Pensamento Conforme Jerome Bruner}

Viu-se como a Ciência Cognitiva se vale dos estudos em Inteligência Artificial, tanto a simbólica quanto a conexionista. Para ambas o pensamento é sinônimo de raciocínio, com causa e efeito.

Bruner não aceita a visão de que o pensamento se expressa somente pela lógica. Para ele, há um outro tipo de pensamento tão ou mais importante que aquele, o pensamento narrativo. O autor enfatiza o papel da narrativa para a construção da identidade do ser humano e para a criação da cultura. Todavia, ele não elabora um modelo de pensamento. Ele enumera características destes dois tipos, porém, para fazê-lo o psicólogo se vale de exemplos das ciências exatas e da teoria literária. $\mathrm{Na}$ verdade, a contribuição do estudo dele reside na abertura de um caminho, antes ignorado pelos cientistas cognitivos, o valor da narrativa para construção de cenários possíveis. Esta dissertação se baseia em algumas concepções de Bruner, entretanto, coloca a questão do pensamento narrativo sob um outro olhar, o do cotidiano. O principal problema na teoria dele está em analisar a narrativa somente com ferramentas da teoria literária, sem se dar conta, que, no dia-a-dia, o homem comum ao pensar não chega a criar histórias com valor literário. Há um parentesco entre a narrativa, por assim dizer, literária e a narrativa do pensamento. Elas podem se assemelhar em alguns pontos e divergir em outros. Esta dissertação trata dos pontos de convergência entre a narrativa literária e narrativa do cotidiano. Neste capítulo, serão 
apresentados os conceitos de Bruner para que no próximo sejam mostradas a releitura e ampliação deles.

\subsubsection{Pensamento Paradigmático}

Bruner (2002), talvez para ser didático, ou por simplificação, relaciona o pensamento paradigmático aos físicos e matemáticos. Explica como o uso da lógica é válido para a elaboração de teoremas. Entretanto, dá a impressão que somente os cientistas possuem este tipo de pensamento. Sabe-se que isso não é verdadeiro, todos nós podemos construir cadeias lógicas; claro que, diferentemente do cientista que deve ser estritamente formal, a maioria das pessoas cria proposições para auxiliar em seus problemas diários. Nesta dissertação, será mostrado isto.

Bruner (2002) levanta as seguintes características do pensamento paradigmático:

- Busca a verdade universal;

- Convence o interlocutor fornecendo provas empíricas;

- Segue a causalidade (se x, então y);

- Forma proposições;

- Preenche um ideal de um sistema formal e matemático de descrição e explicação. Ele emprega a categorização ou a conceituação;

- Regido pela consistência;

De maneira resumida:

\footnotetext{
Um modo, o paradigmático ou lógico científico, tenta preencher o ideal de um sistema formal e matemático de descrição e explicação. Ele emprega a categorização ou a conceituação e as operações pelas quais as categorias são estabelecidas, instanciadas, idealizadas e relacionadas umas às outras para formar um sistema. (...) dispositivos pelos quais as proposições gerais são extraídas de afirmações em seus contextos particulares. (...) sua linguagem é regulada por necessidades de consistência e de não contradição (BRUNER, 2002, p. 14.)
} 


\subsubsection{Pensamento Narrativo}

Como já foi dito, Bruner (2002) não trata do pensamento narrativo no cotidiano do ser humano. Ele analisa exemplos da literatura, citando textos e processo criativo dos escritores. O autor, então, não consegue criar um modelo de funcionamento do pensamento narrativo. Da forma como ele apresenta, parece que o pensamento narrativo seja exclusivo do grupo de literatos. Esta dissertação parte do princípio que não: ele está presente em todos os seres humanos.

Bruner (2002) levanta as principais características do pensamento narrativo, que são as mesmas de um texto literário narrativo:

- Busca a verossimilhança;

- Apresenta condições prováveis entre dois eventos;

- Transgride a consistência podendo ser contraditório;

- Busca a abstração, transcende o particular;

- Existência de gatilho para mudança de um plano para o outro.

No livro A Cultura da Educação, Bruner discute a interpretação narrativa da realidade. Para ele, as narrativas possuem elementos universais responsáveis pela construção da(s) realidade(s). Ele ressalta que "existência de gêneros é universal" (BRUNER, 2001, p.131).

A estrutura do pensamento narrativo está de acordo com os gêneros do discurso internalizados. Bruner (2001, p. 129) diz que:

(...) impossível distinguir de maneira bem definida o que é um modo narrativo de pensamento e o que é um "(...) texto" ou discurso narrativo. Cada um deles dá forma ao outro, do mesmo modo que o pensamento torna-se inextricável da linguagem que o expressa e que o acaba moldando (...). Já que nossa experiência no mundo natural tende a imitar as categorias de nossa ciência conhecida, nossa experiência dos assuntos humanos passa a assumir a forma das narrativas que utilizamos ao contá-los.

Bruner concorda com o estudo Bakhtin (1992, p. 301), que afirma que o homem ao longo da vida domina vários gêneros e estes são usados nas diversas esferas de nossa vida social, como uma espécie de pré-condição para nossa capacidade de comunicação verbal: 
Esses gêneros do discurso nos são dados quase como nos é dada a língua materna que dominamos com facilidade antes mesmo que Ihe estudemos a gramática. A língua materna -a composição de léxico e sua estrutura gramatical-, não a aprendemos nos dicionários e nas gramáticas, nós a adquirimos mediante enunciados concretos que ouvimos e reproduzimos durante a comunicação verbal viva que se efetua com os indivíduos que nos rodeiam.

Bruner (2001, p.136), ao discorrer sobre a importância que a narrativa adquiriu numa sociedade regida cada vez mais pela forma de se contar um acontecimento do que pelo acontecimento em si, afirma:

$\mathrm{Na}$ última metade de nosso século $(X X)$, o drama tornou-se epistemológico, preso não apenas "por aquilo que acontece", mas pelo enigma de como, em um mundo turbulento, passamos a conhecer ou a construir nossas realidades.

Bruner (2001, p.141) enfatiza que a narrativa é um dos meios pelos quais é possível desenvolver o pensamento metacognitivo ${ }^{3}$. Em sua opinião, o papel da narrativa em nossa sociedade é tão importante que as escolas deveriam se esforçar em dar às crianças "maiores oportunidades para a criação da sensibilidade metacognitiva necessária para se lidar com o mundo da realidade narrativa e suas alegações concorrentes".

Bruner (1998, p.129) argumenta:

A implicação mais geral é a de que a cultura se encontra em um constante processo de ser recriada à medida que é interpretada e renegociada por seus membros. Neste ponto de vista, a cultura é tanto um fórum para negociação e renegociação de significado e para explicação da ação quanto um conjunto de regras ou especificações para a ação. De fato, toda cultura mantém instituições especializadas ou ocasiões para intensificação dessa característica "semelhante a um foro". Narração de histórias, teatro, ciência e mesmo jurisprudência são técnicas para a intensificação desta função - maneiras de explorar mundos possíveis a partir do contexto de necessidade imediata.

\footnotetext{
${ }^{3}$ Para Ribeiro (2005) o significado da palavra metacognição é um pouco confuso. Para autora não há um consenso entre os estudiosos, de maneira geral, ela resume: "a metacognição diz respeito, entre outras coisas, ao conhecimento do próprio conhecimento, à avaliação, à regulação e à organização dos próprios processos cognitivos. De acordo com Weinert (1987), as metacognições podem ser consideradas cognições de segunda ordem: pensamentos sobre pensamentos, conhecimentos sobre conhecimentos, reflexões sobre ações". Não cabe entrar nesta discussão. Esta dissertação considera metacognição como o ato de pensar sobre o próprio pensamento.
} 
De todo o estudo de Bruner, aqui resumido, conclui-se que ele não cria um modelo. Sua contribuição para o estudo da mente está em mostrar que o homem é um ser sócio-cultural e criador de realidades possíveis expressas pelo pensamento narrativo.

Esta dissertação propõe um modelo simplificado que leve em conta alguns aspectos do pensamento narrativo e paradigmático, enfatizando a interação entre eles. 


\section{Aristóteles: Conceitos Norteadores}

O homem é um ser que interage com seu meio. As informações externas são captadas por seus sentidos e reorganizadas em sua mente. Esta "realidade" capturada não é ingênua. O homem está inserido em uma teia sócio-cultural da qual ele não pode se ver desprendido. Ele vive o cotidiano e age sobre ele. Heller (1972) afirma que esta ação é fragmentada, já que o ser humano não dá conta da totalidade de acontecimentos ao seu redor; há como um recorte no que lhe é apresentado. O próprio cotidiano, em sua temporalidade rotineira, impõe aos homens a necessidade de reações imediatas. Estas reações rápidas acabam gerando ultrageneralizações, que funcionam como um recurso operacional-prático. A formação de juízos provisórios é necessária para atender às demandas da vida social cotidiana, mas podem cristalizar-se em preconceitos, ultrageneralizações negativas. As características do comportamento cotidiano, ou seja: espontaneidade, pragmatismo, economia, julgamentos provisórios baseados em precedentes, analogias, imitações, são os elementos, segundo Heller (1972) que tornam a vida cotidiana a esfera da realidade. Para Kosik (1989, p. 69) "A vida cotidiana é antes de tudo organização, dia-a-dia, da vida individual dos homens; a repetição de suas ações vitais é fixada na repetição de cada dia, na distribuição do tempo em cada dia".

Esta dissertação considera que o mundo criado pelo ser humano pode ser organizado em narrativas cotidianas, ou seja, são narrativas criadas a partir do cotidiano sem uma preocupação com a literariedade ${ }^{4}$. Narrativas literárias e cotidianas possuem em comum elementos primitivos organizadores do enredo. São eles:

\footnotetext{
${ }^{4}$ Jakobson, em 1919, tentou definir como literariedade a propriedade específica do texto, que lhe dá a dimensão estética e plurissignificativa capaz de estabelecer as mais variadas relações de sentido. Com o predomínio da função poética da linguagem, as palavras são combinadas no discurso, explorando recursos lingüísticos nos planos fônico, prosódico, léxico, morfológico, sintático e semântico.
} 
- Personagens: agentes da(s) ação(ões).

- Narrador: quem conta a história.

- Espaço: onde ocorre a ação.

- Tempo: quando ocorre a(s) ação(ões).

- Ações: fatos que ocorrem na história.

A narrativa cotidiana, para este trabalho, é a narrativa do pensamento humano. Sendo assim, o indivíduo que pensa narrativamente seria um narrador observador (o que corresponde ao narrador em terceira pessoa da Teoria Literária) e/ou aquele que viveu dos fatos (seria o narrador em primeira pessoa da Teoria Literária). Não haveria correspondência entre o narrador onisciente da literatura na narrativa cotidiana, já que o homem não pode saber exatamente o que as outras pessoas (personagens) pensam.

A narrativa cotidiana, além destes elementos primitivos apresenta outra semelhança com a narrativa literária: o gênero. $O$ termo gênero é de difícil definição e categorização. Segundo Bakhtin (1992) existe muita dificuldade em classificar os gêneros, já que estes são entidades dinâmicas passíveis de transformações de acordo com as condições sociais e históricas em que são produzidos. Entretanto, mesmo havendo mudanças há sempre elementos estáveis que permanecem e garantem a sua identificação pela pessoa. Pode-se dizer que eles integram passado e presente e, ao mesmo tempo, evoluem para responder às mudanças sócioculturais. Conforme Bakhtin (1992), a comunicação entre os seres humanos só é possível através da existência dos gêneros. Ele afirma que cada comunidade tem seus objetivos particulares e, assim, a própria comunidade define quais gêneros são relevantes para ela, ou seja, um gênero compreende uma classe de eventos comunicativos, cujos membros compartilham os mesmos propósitos comunicativos. O autor afirma que haverá tantos gêneros de discurso quanto houver atividades humanas. Portanto, percebe-se como é difícil a conceituação de gênero. Além de seu repertório ser ilimitado, os critérios normalmente usados para sua 
classificação estão em interação constante, são mutáveis, podendo-se imbricar com outros gêneros, emergir ou simplesmente desaparecer. Mas isso não quer dizer que não é possível delinear algumas características padrão de um determinado gênero. Para isto, é importante um estudo de sua história e a análise minuciosa para saber o que se manteve e o que se perdeu.

O estudo do gênero está ligado ao estudo do texto e mais precisamente ao literário. Sabe-se que não será tratada a narrativa literária, mas a cotidiana, sendo que esta apresenta como ponto em comum com aquela o gênero. Como já foi dito, a classificação dos gêneros é muito complexa por causa de sua variedade. Para o presente estudo é necessário estabelecer um critério de seleção. A escolha recaiu sobre dois assuntos, que estão nos meios de comunicação de massa constantemente e fazem parte do dia-a-dia das pessoas, a violência e o romance. Estes assuntos pertencem a dois gêneros: o policial e o romântico. Para definir quais características pertencem a estes gêneros, partiu-se de textos literários, entretanto, sendo selecionados elementos que se repetem e definem o perfil deste gênero, não sendo levado em conta a estilística. A seguir será feita uma apresentação destes gêneros na literatura, para depois explicar quais de suas características são importantes para o modelo proposto.

\subsection{Gênero Romântico: Folhetim}

Mayer (1996) fez um longo estudo sobre o folhetim e como eles foram importantes para a literatura brasileira. A autora aponta autores do século XIX como José de Alencar, Joaquim Manuel de Macedo, Manuel Antonio de Almeida e Machado de Assis como representantes deste gênero. Ela afirma que o folhetim começou na França, em 1830, com Émile de Girardin, ele queria ampliar o consumo de jornais, junto às classes populares e usou de expedientes que poderiam baratear as publicações. Criou então, o "rodapé" do jornal, lugar onde seriam publicadas miscelâneas e variedades, o 
chamado fait-divers. Nesse espaço começou a introduzir romances em partes, fazendo ganchos, numa constante referência à edição anterior, surgindo o "continua na próxima edição". Este seria o início do folhetim/romance e folhetim tout court. Nesse sentido, a fragmentação da narrativa, constituindo-se em um quebra-cabeça que será reconstruído, remontado pelo leitor, define o gênero folhetim e sua estrutura estética. A autora analisa também a representação social da época nestes textos.

Não cabe aqui estender este assunto, é fundamental perceber que este gênero é muito familiar até hoje (através da telenovela) na cultura principalmente dos países da América Latina. Desta forma, este tipo de gênero está incorporado na vida das pessoas. A criação do estereótipo da mocinha e mocinho ${ }^{5}$ faz parte do imaginário coletivo. Deste gênero podemse extrair algumas características fundamentais:

- O motivo que desencadeia a trama: o interesse afetivo de uma das personagens pela outra.

- Conflitos: acontecimentos que impedem a concretização do amor no primeiro instante. Tradicionalmente, outra personagem se coloca entre o casal de apaixonados.

- Final: na literatura e na televisão se sobressai o final feliz, porém, neste trabalho como se fala em narrativa cotidiana, isso não quer dizer que necessariamente ocorra.

No programa "Aristóteles" foram escolhidas palavras-chave que determinam este gênero, assim como situações padrão. Estes detalhes serão expostos no capítulo 4.

\subsection{Gênero Policial}

\footnotetext{
${ }^{5}$ Os termos mocinho e mocinha foram escolhidos para denominar as personagens principais que formam o casal romântico. Para facilitar, este trabalho leva em consideração o padrão: mocinho quer conquistar a mocinha. Todavia, é necessário registrar que a narrativa cotidiana representando o momento histórico atual também leva em conta o inverso: a mocinha em busca do amor do mocinho.
} 
Tvetan Todorov (2004) faz um estudo das estruturas narrativas do gênero policial; seus diversos tipos surgidos ao longo da história e suas características fundamentais. Para este trabalho não cabe levantarmos a tipologia feita pelo autor. Considera-se que havendo um crime (ou vários) e um observador, seja o próprio investigador ou alguém de fora da ação, terse-á uma narrativa policial.

Do estudo de Todorov (2004) pode-se concluir que o universo do romance policial é permeado por vários elementos: medo, mistério, investigação, curiosidade, assombro, inquietação, que são dosados de acordo com os autores e as épocas. Através da palavra, o medo se torna uma tortura da imaginação e estabelece uma relação poética entre narrador e leitor. O temor diante do desconhecido e o espanto, como resultado da resolução de um enigma baseado na investigação racional, caracterizam a essência da narrativa policial. Então as características fundamentais deste gênero são:

- Há um ou mais crimes.

- Há um ou mais suspeitos.

- Há o detetive que colhe as evidências

- Há a descoberta do criminoso.

Como este trabalho trata da narrativa do cotidiano, o papel do detetive não precisa ser necessariamente exercido por alguém da lei. Uma pessoa comum que leu no jornal sobre um crime, ou desconfia de alguém próximo também pode colher provas e incriminar alguém.

O programa "Aristóteles" seleciona palavras-chave e situações padrão para determinar este gênero. No Capítulo 4 serão mostrados mais detalhes.

\subsection{Comparação entre os Conceitos de Bruner e os Conceitos Representados pelo Modelo Aristóteles}

Levando em consideração o papel social do homem, sua interação com os demais e a formulação de cenários mentais possíveis, o modelo Aristóteles parte das seguintes afirmativas: 
- O pensamento narrativo constrói "mundos possíveis" em nossa mente. Porém, para que tenha um reflexo concreto na sociedade, ele deve se tornar uma atitude. Para tanto, o ser humano tira conclusões da história pensada, estas conclusões, denominadas aqui de proposições, são norteadoras de possíveis ações do ser humano.

- O gênero representa o conhecimento adquirido pelo indivíduo, o que facilita a comunicação e o entendimento humano, resultante da interação entre os seres humanos. Ao construir a sua narrativa interna, o homem cria uma expectativa sobre o que pode acontecer baseado no gênero ao qual relaciona a narrativa. Esta expectativa se expressa na forma de uma pergunta. Tem-se como resposta, a proposição.

- A proposição aqui é a resposta gerada a partir da narrativa. Não entrará em discussão a definição de proposição para filosofia e ciências exatas, à qual Bruner faz menção.

É importante dizer que, apesar de existirem narrativas em primeira pessoa, para facilitar a realização do modelo, parte-se da observação, ou seja, a história criada é em terceira pessoa e a expectativa está em descobrir o que irá acontecer com os personagens.

Este modelo não explicita a relação sociedade/ pensamento do indivíduo. Parte-se do princípio que qualquer história criada e proposições derivadas sejam influenciadas e influenciam a sociedade ao redor.

Abaixo, a Tabela 3-1 mostra a comparação entre os conceitos apresentados por Bruner e os utilizados no "Aristóteles". É importante reafirmar que Bruner não chega a criar um modelo de pensamento narrativo e pensamento paradigmático. 
Tabela 4-1 Comparação entre os conceitos de Bruner e os aplicados em "Aristóteles".

\begin{tabular}{|c|c|c|}
\hline Conceitos & em Bruner & em "Aristóteles" \\
\hline $\begin{array}{l}\text { Pensamento } \\
\text { Narrativo }\end{array}$ & $\begin{array}{l}\text { Não há uma definição precisa. Há } \\
\text { um conjunto de características } \\
\text { levantadas pelo autor. Todas } \\
\text { transpostas do campo da Teoria } \\
\text { Literária. }\end{array}$ & $\begin{array}{l}\text { Pensamento lingüístico expresso } \\
\text { na forma de narrativa. }\end{array}$ \\
\hline Narrativa & Literária & $\begin{array}{l}\text { Cotidiana (interação/reflexo sócio- } \\
\text { cultural do homem no seu dia-a- } \\
\text { dia) }\end{array}$ \\
\hline Gênero & $\begin{array}{l}\text { Padrões encontrados que permitem } \\
\text { dizer se tal texto/discurso pertence } \\
\text { a este ou aquele gênero. É } \\
\text { internalizado conforme acontece a } \\
\text { interação social. }\end{array}$ & Mesma definição de Bruner. \\
\hline $\begin{array}{l}\text { Pensamento } \\
\text { Paradigmático }\end{array}$ & $\begin{array}{l}\text { Não há uma definição precisa. Há } \\
\text { um conjunto de características } \\
\text { levantadas pelo autor. Todas } \\
\text { transpostas do campo das ciências } \\
\text { exatas. }\end{array}$ & $\begin{array}{l}\text { Pensamento lingüístico expresso } \\
\text { por proposições. }\end{array}$ \\
\hline Proposição & Sentença lógica. & $\begin{array}{l}\text { Conclusão expressa por uma } \\
\text { sentença bem construída. }\end{array}$ \\
\hline
\end{tabular}

A tabela 3-1 mostra como os conceitos de Bruner foram reavaliados e a contribuição teórica feita por esta dissertação.

\subsection{Contribuições e potencialidades}

Esta dissertação apresenta um novo enfoque sobre a teoria do psicólogo Bruner e uma representação desta corrente. Durante muitos anos o "pensamento" humano foi estudado somente baseado na sua capacidade lógica de ordenar sentenças, criar inferências e deduzir conclusões. $\mathrm{Na}$ 
década de 60 a Inteligência Artificial, principalmente a simbólica, tomou como ponto de partida estas características para desenvolver programas "inteligentes". Questões referentes à capacidade destes sistemas, vistos em um primeiro momento como muito potentes, colocaram a IAS no foco das críticas. Autores como Searle e Penrose foram alguns dos opositores, como já foi comentado no capítulo 2. Bruner, em certa medida, apóia estes autores e vai mais longe ao afirmar que a Ciência Cognitiva, ao se aliar à IA, estava reduzindo o estudo do pensamento a algo tecnicista e vazio em conteúdo. Para este psicólogo a Ciência Cognitiva deveria agregar a seus modelos elementos culturais e ideológicos. A narrativa seria uma fonte destes elementos, já que ela se alimenta deles e está em constante interação com eles. Daí parte seu estudo de pensamento narrativo. Como analisado anteriormente, o psicólogo não chega a criar um modelo, entretanto, seu estudo é muito importante, pois abre caminho para o debate sobre o conceito de "pensamento" menos relacionado à lógica e mais voltado para a sua interação com a sociedade. Esta dissertação contribui para uma discussão em que a narrativa e a proposição estão relacionadas, ou seja, se é possível entender o pensamento como um processo integrador entre a lógica e a cultura, se reduzirmos a lógica à proposição e a narrativa aos seus elementos primitivos (personagem, narrador, espaço, tempo e ação). Outra contribuição fundamental é dar importância ao gênero como um arcabouço composto por padrões de narrativas geradas a partir da comunicação social.

O software "Aristóteles" é uma representação simplista de todos estes conceitos complexos. A versão apresentada é a primeira e merece, sem dúvida, muitas ampliações (vide capítulo 6), mas mesmo com suas limitações ela serve para comprovar que é possível se extrair proposições a partir de narrativas.

Sendo assim, este trabalho contribui para a pesquisa na área de Ciência Cognitiva porque dá uma nova roupagem para o estudo de Bruner e demonstra como é possível representar conceitos complexos a partir de uma base lógica simples. Seu potencial é grande, podendo ser ampliado e usado 
na área da educação. Alunos podem escrever histórias coerentes e tentar descobrir a qual gênero pertence sua narrativa, e depois conferir a resposta com o software. Ou mesmo usá-lo como auxiliar no ensino de coesão e coerência: o professor pode usar o programa para mostrar como a relação entre as sentenças e os parágrafos faz com que o texto seja claro. A seguir será vista com mais profundidade a primeira implementação do "Aristóteles", ou seja, a versão mais simples. No futuro, ela deve ser ampliada com mais funções, se tornando assim, mais inteligente. 


\section{Aristóteles: Implementação}

Até agora foram mostrados os conceitos que serviram de base para a criação do software "Aristóteles", como eles foram adaptados e reavaliados. A partir deste capítulo será apresentado o software em si. O "Aristóteles" foi escrito em linguagem Java por esta ser multi-plataforma e orientada a objetos. A Inteligência Artificial inspirou a construção deste software já que foram usados símbolos e uma adaptação do Sistema Especialista (SE). Estas características serão detalhadas no decorrer do texto.

A sua interface possui, para cada sentença, seis campos a serem preenchidos pelo usuário, a saber:

- sujeito,

- verbo,

- objeto um,

- objeto dois,

- advérbio de tempo,

- advérbio de espaço.

A interface do "Aristóteles" é simples e de fácil uso. A Figura 4-1 identifica os campos da interface. 


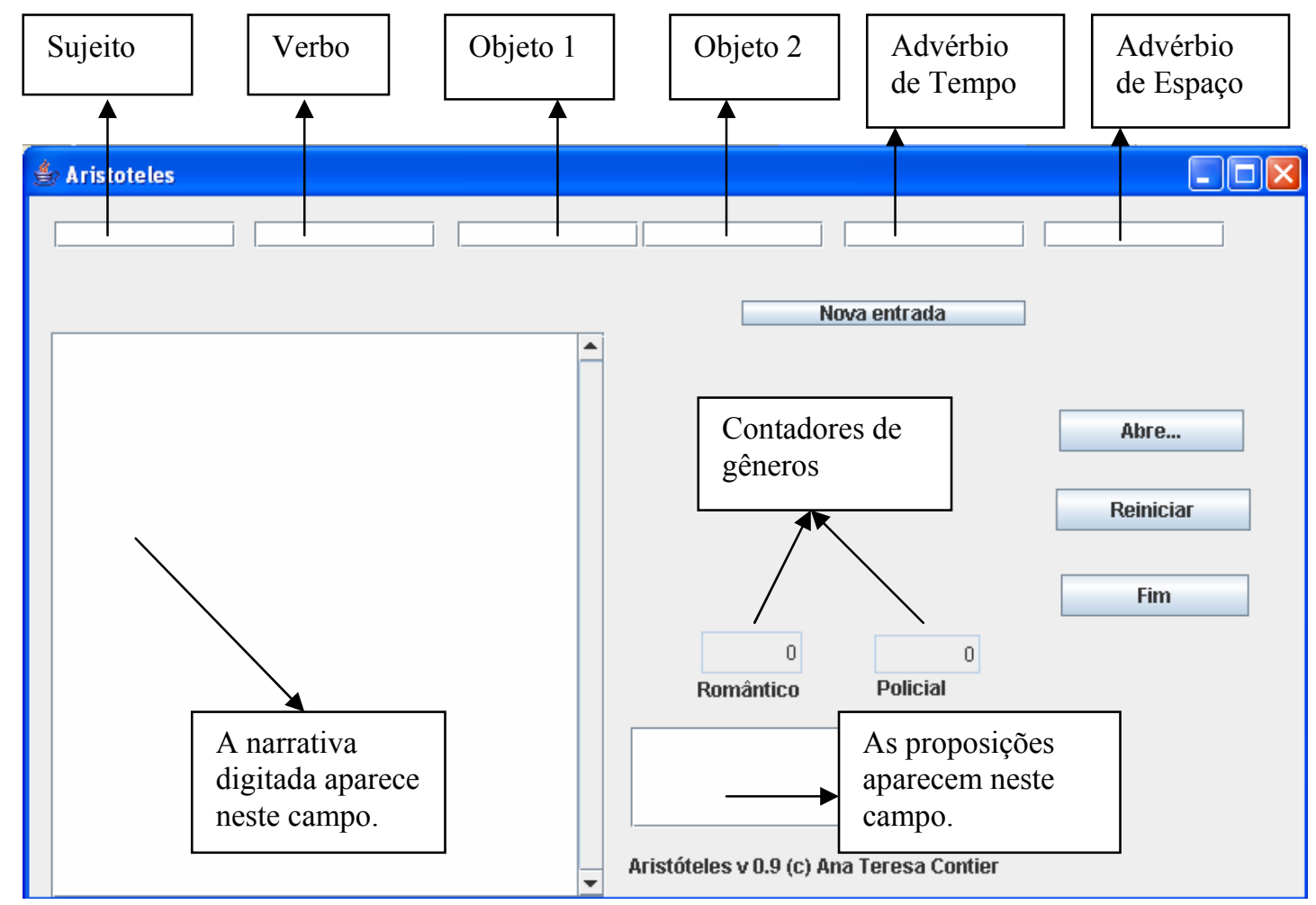

Figura 5-1 Interface gráfica "Aristóteles".

O usuário deve preencher cada um dos campos correspondentes às funções sintáticas destacadas (Figura 4-1). Com a sentença formada, ele deve selecionar "nova entrada". Conforme o usuário preenche os campos formando orações, elas irão parecendo no canto esquerdo da tela (Figura 41). O conjunto de orações digitado formará a narrativa.

As palavras digitadas formam uma sentença ("texto narrativo simples"). Este texto será classificado em dois possíveis gêneros, narrativa policial e narrativa romântica. Conforme a classificação, o programa procura responder a questões que são inerentes a cada um destes gêneros, por exemplo, no policial, quem é o assassino e no romântico se o amor do casal principal será consagrado. A narrativa criada é uma analogia muito simples ao pensamento narrativo e a resposta dada representa, de forma simples, o pensamento paradigmático.

Se a palavra digitada pertencer ao dicionário de um determinado gênero, o contador do gênero correspondente se alterará. $O$ usuário, ao 
selecionar a tecla "Fim", encerra esta contagem. Aquele gênero, que possuir então o maior valor, será o classificador da história.

Tendo sido definido o gênero, a resposta à questão chave deste gênero será apresentada no campo inferior à direita da tela (Figura 4-1)

Se o usuário quiser escrever outra história, basta selecionar "Reiniciar" para recomeçar todo o processo. Se ele quiser escolher uma história do arquivo, ele deve clicar no botão "Abre" e selecionar o texto. Entretanto, a narrativa deve seguir os moldes pré-estabelecidos, ou seja, a mesma gramática de entrada.

Neste capítulo serão apresentados: a gramática de entrada e a arquitetura do programa.

\subsection{Gramática de Entrada}

O usuário deve criar uma narrativa que siga algumas regras básicas para evitar incoerências e ambigüidades no texto. Sendo assim foi definida uma gramática de entrada que deve estar de acordo com duas premissas:

- Serão admitidas somente orações simples: SUJEITO + VERBO + OBJETOS + ADVÉRBIO DE TEMPO + ADVÉRBIO DE ESPAÇO.

- Histórias são narradas em $3^{a}$ pessoa. As personagens são observadas pelo narrador, ou seja, o usuário do programa.

A interface possui seis campos correspondentes às cinco funções (como o verbo pode ser bitransitivo, há dois campos referentes ao objeto) para garantir que a história criada tenha somente orações simples. Para garantir que não aja ambigüidade foi criada uma série de regras a serem seguidas pelo usuário ao digitar sua narrativa. A seguir temos a descrição dos campos e as regras correspondentes ${ }^{6}$.

\footnotetext{
${ }^{6}$ Para facilitar o reconhecimento dos termos pelo programa, algumas concessões foram feitas: o advérbio de tempo foi reduzido à forma dia/mês/ano; locuções verbais formadas pelos verbos ser / estar + particípio/ gerúndio devem ser separadas (ser/estar devem ficar no campo "verbo" e particípio/gerúndio devem ficar no campo "objeto"); predicado nominal (verbo ser + adjetivo) deve ser desmembrado sendo o verbo "ser" colocado no campo
} 
Para as tabelas a seguir foi adotada a seguinte legenda:

$$
\begin{aligned}
& \mathrm{N}=\text { nome próprio ou substantivo comum } \\
& \mathrm{R}=\text { artigo (a/ as; o/ os; um/ uns; uma/ umas) } \\
& \mathrm{A}=\text { adjetivo } \\
& \mathrm{V}=\text { verbo } \\
& \mathrm{dd} / \mathrm{mm} / \text { yyyy = dia / mês / ano }
\end{aligned}
$$

Tabela 5-1 Regras sintáticas do campo sujeito.

\begin{tabular}{|l|l|}
\hline Campo & Sujeito \\
\hline Descrição & $\begin{array}{l}\text { Quem faz a ação. Na narrativa se for nome próprio exerce o } \\
\text { papel de personagem. }\end{array}$ \\
\hline Regra 1 (R1) & Não aceita pronomes do caso reto (eu/tu/ele/nós/vós/eles). \\
\hline Regra 2 (R2) & Aceita a forma N. \\
\hline Regra 3 (R3) & Aceita a forma RN. \\
\hline Regra 4 (R4) & Aceita a forma RNA ou somente NA. \\
\hline Regra 5 (R5) & $\begin{array}{l}\text { Não aceita pronomes demonstrativos: este(s), esta(s), isto; } \\
\text { esse(s); essa(s), isso; aquele(s); aquela(s); aquilo. }\end{array}$ \\
\hline
\end{tabular}

Tabela 5-2 Regras sintáticas do campo verbo.

\begin{tabular}{|l|l|}
\hline Campo & Verbo \\
\hline Descrição & Indica a ação da narrativa. \\
\hline Regra 1 (R1) & $\begin{array}{l}\text { Aceita somente verbo no infinitivo, ou seja, palavra terminada em } \\
\text { "r". }\end{array}$ \\
\hline Regra 2 (R2) & Não aceita verbo no gerúndio ou particípio. . \\
\hline Regra 3 (R3) & $\begin{array}{l}\text { No caso do verbo ser + A ou estar + A, aceita somente "ser" e } \\
\text { "estar", sendo. A deve ser colocado no campo "objeto. }\end{array}$ \\
\hline Regra 4 (R4) & Aceita "não" na frente do verbo. \\
\hline
\end{tabular}

Tabela 5-3 Regras sintáticas dos campos objeto 1 e objeto 2.

\begin{tabular}{|l|l|}
\hline Campo & Objetos 1 e 2 \\
\hline Descrição & $\begin{array}{l}\text { Complemento do verbo. Na narrativa, se for nome próprio } \\
\text { representa o personagem. }\end{array}$ \\
\hline Regra 1 (R1) & $\begin{array}{l}\text { Não aceita pronomes do caso oblíquo (me, te/ti, lhe, nos, vos, } \\
\text { Ihes). }\end{array}$ \\
\hline
\end{tabular}

"verbo" e o "adjetivo" no campo "objeto". Desta forma os campos "objeto 1 e 2" não representam necessariamente a função "objeto" da gramática normativa e o campo "tempo" não expressa o "advérbio de tempo" em sua totalidade. 


\begin{tabular}{|l|l|}
\hline Regra 2 (R2) & Aceita a forma N ou NN. \\
\hline Regra 3 (R3) & Aceita a forma RN. \\
\hline Regra 4 (R4) & Aceita a forma RNA ou somente NA. \\
\hline Regra 5 (R5) & $\begin{array}{l}\text { Não aceita pronomes demonstrativos: este(s), esta(s), isto; } \\
\text { esse(s); essa(s) isso; aquele(s); aquela(s); aquilo. }\end{array}$ \\
\hline Regra 6 (R6) & Aceita a forma A. \\
\hline Regra 7 (R7) & Aceita V no particípio ou gerúndio. \\
\hline
\end{tabular}

Tabela 5-4 Regras sintáticas do campo advérbio de tempo.

\begin{tabular}{|l|l|}
\hline Campo & Advérbio de tempo \\
\hline Descrição & Quando a ação ocorre. Representa o tempo da narrativa. \\
\hline Regra 1 (R1) & Aceita somente a forma dd/mm/yyyy. \\
\hline Regra 2 (R2) & Aceita as palavras "amanhã", "hoje", "ontem". \\
\hline
\end{tabular}

Tabela 5-5 Regras sintáticas do campo advérbio de lugar.

\begin{tabular}{|l|l|}
\hline Campo & Advérbio de lugar \\
\hline Descrição & Onde ocorreu a ação. Representa o cenário da narrativa. \\
\hline Regra 1 (R1) & Aceita "em", "no", "na", "nos", "nas", "de"+ N. \\
\hline Regra 2 (R2) & Aceita a forma N, NN. \\
\hline
\end{tabular}

\subsection{Arquitetura do Programa}

O programa "Aristóteles" escrito em Java possui as seguintes classes:

- Conceito: armazena as palavras, de forma que se elas se repetirem no texto, não serão duplicadas. Cada conceito pode ter atributos, que são conceitos também. Em suma, conceito = palavra.

- AdmConceito: classe que administra a lista de conceitos conhecidos.

\footnotetext{
${ }^{7}$ O tempo da narrativa é um conceito muito complexo na Teoria Literária. Resumidamente, há o tempo dos fatos narrados e o tempo da narração. O programa não leva em conta isso, mesmo se tratando de uma "narrativa do cotidiano" em que pode haver estes dois tipos de tempo. O usuário deve digitar quando a ação aconteceu e para verbos como amar, gostar colocar a data em que supostamente o sentimento aflorou ou ,se achar irrelevante para a trama, deixar o campo em branco.
} 
- Categoria: classe base abstrata, instanciadas por cada um dos 6 campos de texto da interface a serem preenchidos. Apesar de serem especializações diferentes (Verbo, Sujeito etc.), eles têm uma base igual, ou seja, serem compostos de Conceitos. A classe Categoria serve para dar uma interface unificada para estas subclasses, permitindo seu fácil acesso pelo resto do programa. As classes Sujeito, Verbo, Objeto, Local, derivadas da classe Categoria, implementam as regras de sintaxe e de parsing.

- SentencaNarrativa: o composto de Sujeito+Verbo+Obj1+Obj2+ Data+Local, que forma uma sentença completa.

- PensamentoNarrativo: A lista de SentencaNarrativas.

- Nomes: lista dos nomes masculinos e femininos, para identificação no texto.

- Genero: classe pai abstrata. Todos os tipos de gênero herdam desta classe. Serve para fornecer uma interface padrão para o que cada subclasse deve fazer.

- Policial e Romantico: implementam os algoritmos de reconhecimento/processamento destes gêneros, de acordo com a interface da classe Genero.

- AdministradorGenero: uma classe utilitária que armazena todos os tipos de gêneros suportados pelo programa. É essencialmente uma lista com alguns métodos básicos; estes métodos evitam ter que chamar cada um dos gêneros da lista para fazer uma operação. $A$ classe se encarrega de varrer esta lista.

- Pesos: contém pesos de cada palavra-chave.

- AssociaçãoNota: contém as notas a serem dadas para as sentençaschave de cada gênero.

- Aristóteles: interface gráfica

- TestRun: interface não gráfica.

- ExcecaoAlerta: classe que implementa as exceções internas. 
A seguir apresentamos o diagrama UML destas classes. O diagrama foi dividido em duas figuras para facilitar a leitura. 


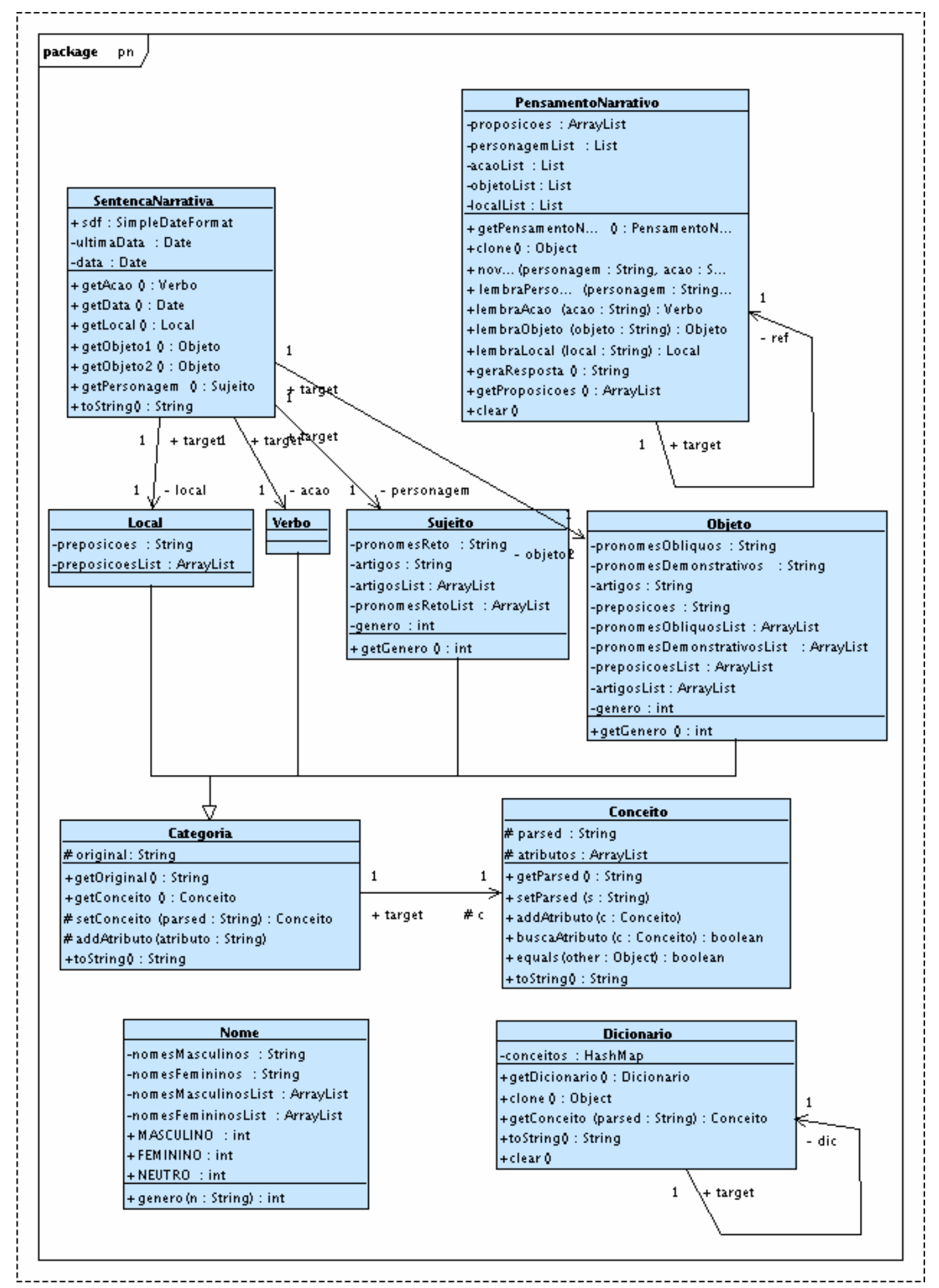

Figura 5-2 Diagrama UML "Aristóteles". 


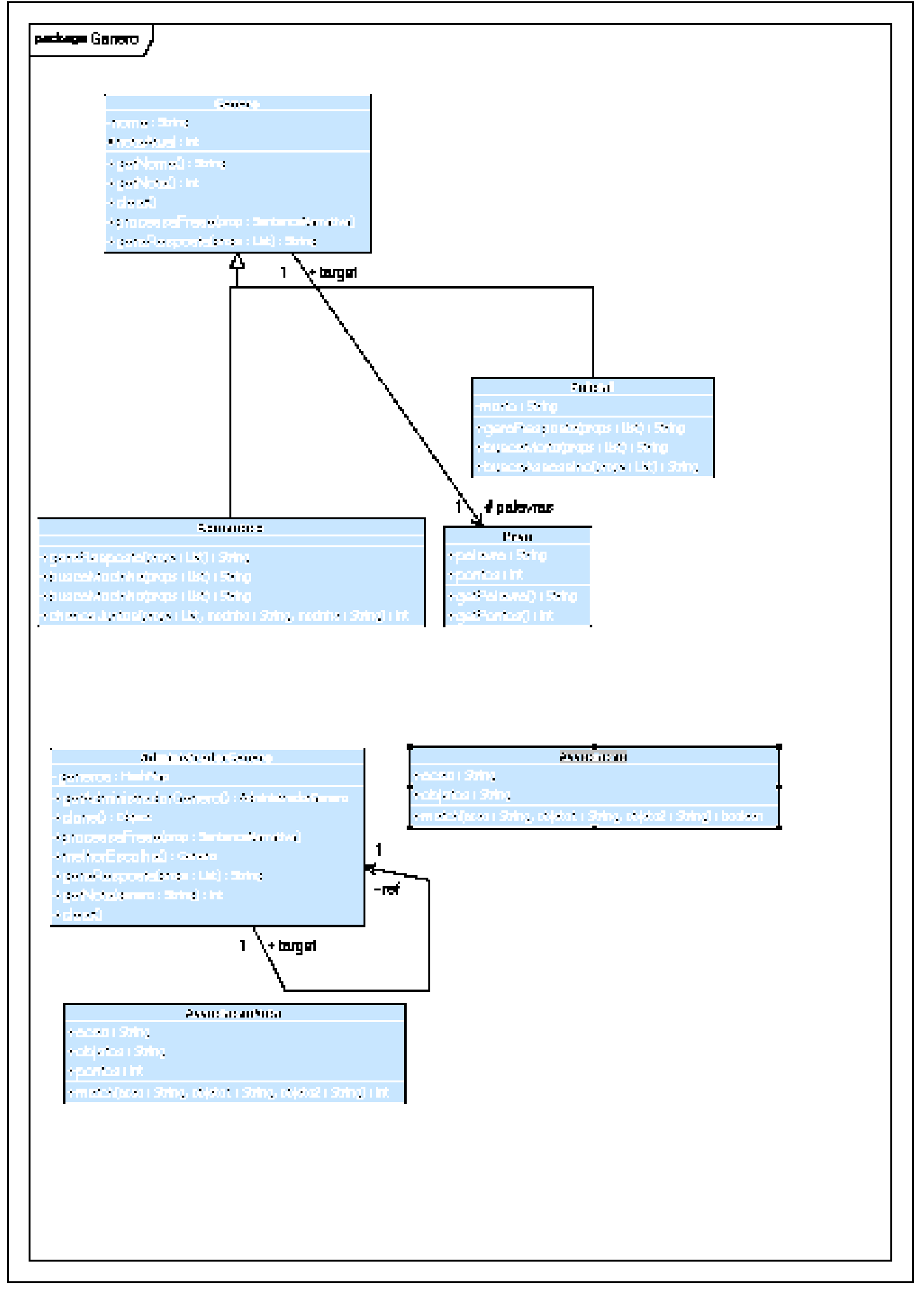

Figura 5-3 Diagrama UML "Aristóteles" (continuação) 
É importante frisar que a arquitetura do "Aristóteles" é flexível, sendo possível adicionar novas classes de gênero apenas instanciando uma classe filha da Gênero. Isto facilita uma futura ampliação do software.

Ficou claro que os dados de entrada formam sentenças e seu conjunto representa o Pensamento Narrativo. A narrativa criada será classificada em policial ou romântica de acordo com suas características. A saída do programa é uma proposição (pensamento paradigmático) que responde a uma pergunta típica do gênero determinado. A seguir a especificação de como o programa define o gênero e busca a resposta para a pergunta pré-definida.

\subsubsection{Gênero}

A classe Gênero e suas subclasses têm papel fundamental para este programa. Elas são semelhantes a um SES, usando porém regras bem simples. Como um especialista em gênero, estas classes analisam as narrativas digitadas e as classificam em policial e romântica. Para esta classificação, é consultado um diário com palavras-chave. Cada palavra possui um peso. Assim, toda a vez que a palavra aparecer no texto o gênero correspondente recebe um valor. Desta forma, a narrativa será classificada pelo gênero que tiver maior pontuação.

Cada gênero possui uma questão inerente a ele. Para encontrar a resposta a esta questão inerente, um diário foi criado com as sentenças características de determinado gênero. Este diário possui pesos para estas sentenças e, dependendo da somatória dos pesos das sentenças achadas no diário, pode-se determinar a resposta. As palavras e sentenças para o gênero romântico foram escolhidas através do estudo de textos de folhetins: A Moreninha de Joaquim Manuel de Macedo; Memórias de um sargento de milícias de Manuel Antonio de Almeida; Mão e a Luva e Helena ambos de Machado de Assis; A Dama das Camélias, de Alexandre Dumas Filho; Notre Dame de Paris (O corcunda de Notre Dame) de Victor Hugo; Amor de Perdição de Camilo Castelo Branco; Pupilas do Senhor Heitor de Júlio 
Dinis entre outros. Para os policiais: Os crimes da Rua Morgue de Edgar Allan Poe; diversos contos de Sherlock Holmes de Arthur Conan Doyle; Assassinato no Expresso Oriente e 0 caso dos dez negrinhos de Agatha Christie. Como já foi explicado no capítulo 3, esta dissertação está preocupada com a "narrativa cotidiana" que é alimentada pela "literária", sendo assim, parte-se de texto literários deixando de lado a estilística.

Os pesos foram escolhidos baseados nestes textos acima, ou seja, são sentenças e palavras que são mais prováveis de aparecerem nestes contextos. É importante deixar claro para esta primeira versão foram determinados este dicionário e diário, porém, estão sendo avaliados os recursos da Tecnologia Adaptativa ${ }^{8}$ para que o programa consiga aprender novas regras e/ou reforçar as antigas, atribuindo pesos mais representativos.

\subsubsection{Definição do gênero}

Para definir o gênero, foi criado um dicionário com palavras-chave que caracterizam cada gênero. Entretanto, uma mesma palavra pode pertencer a ambos. Para resolver este problema, foi estabelecida a seguinte métrica:

- 0 = muito pouco provável

- 1 = pouco provável

- 3 = provável

- 5 = muito provável

A tabela 4-6 mostra as palavras-chave e seus pesos:

\footnotetext{
${ }^{8}$ Esta dissertação não aborda Tecnologia Adaptativa, porém, entende que seu estudo é de grande valia para o aprimoramento deste programa, já que, “ o formalismo adaptativo mostra-se uma alternativa bastante natural para a modelagem de soluções na área de aprendizagem computacional, uma vez que é capaz de capturar um aspecto fundamental da aprendizagem: a adaptação dinâmica das estruturas internas de um mecanismo em função de sua interação com o ambiente” (PISTORI, 2003, p. 2)
} 
Tabela 5-6 Palavras-chave e seus pesos.

\begin{tabular}{|l|l|l|}
\hline Palavras-chave & Romântico & Policial \\
\hline arma & 1 & 5 \\
\hline vulto & 1 & 5 \\
\hline sangue & 3 & 5 \\
\hline morte & 0 & 5 \\
\hline morto/a & 0 & 5 \\
\hline tiro & 1 & 5 \\
\hline veneno & 1 & 5 \\
\hline corpo & 1 & 5 \\
\hline medo & 1 & 3 \\
\hline assustado/a & 1 & 3 \\
\hline barulho & 1 & 3 \\
\hline grito & 1 & 5 \\
\hline pânico & 1 & 3 \\
\hline escuridão & 0 & 3 \\
\hline ensangüentado/a & 1 & 3 \\
\hline envenedado/a & 1 & 3 \\
\hline esfaqueado/a & 1 & 3 \\
\hline rosa & 3 & 0 \\
\hline flor & 3 & 0 \\
\hline chocolate & 3 & 0 \\
\hline beijo & 5 & 3 \\
\hline carta & 5 & 3 \\
\hline e-mail & 5 & 3 \\
\hline presente & 5 & 3 \\
\hline jóia & 5 & 3 \\
\hline apaixonado/a & 5 & 3 \\
\hline amor & 5 & 3 \\
\hline amar & 5 & 3 \\
\hline ligar & 5 & 3 \\
\hline beijar & 5 & 3 \\
\hline telefonar & 5 & 3 \\
\hline escrever & 5 & 3 \\
\hline apaixonar & 5 & \\
\hline & & 3 \\
\hline
\end{tabular}

Cada vez que estas palavras aparecem no texto, seu valor será somado ao gênero correspondente. $O$ gênero que possuir maior valor absoluto será escolhido como o que define a narrativa.

\subsubsection{Gênero romântico}

Se o gênero da narrativa for o romântico, a pergunta pré-definida característica dele é:

- O mocinho conquista a mocinha?

Então o primeiro passo é descobrir quem é o casal principal. 


\section{Para descobrir quem é a mocinha:}

As seguintes etapas são percorridas:

- Procurar nomes femininos nos campos "sujeito" e "objetos".

- Verificar se a ação relacionada ao nome se encontra no diário.

- Dar o valor correspondente para o nome encontrado.

As sentenças relacionadas à mocinha possuem uma nota que pode ser 1, 3 ou 5 .

Tabela 5-7 Sentenças da "mocinha" e seus valores.

\begin{tabular}{|l|c|}
\hline Sentenças & Nota \\
\hline Receber (flor(es), chocolate(s), jóia(s), presente(s), carta(s), e-mail(s)) & 1 \\
\hline Beijar & 3 \\
\hline Apaixonar & 3 \\
\hline (ser/estar) apaixonada & 3 \\
\hline Amar & 5 \\
\hline Dar presente & 1 \\
\hline Declarar amor & 5 \\
\hline
\end{tabular}

A personagem feminina que possuir maior nota será a mocinha.

\section{Para descobrir quem é o mocinho}

O mesmo algoritmo da "mocinha" é usado, buscando-se porém um nome masculino. $O$ nome deve estar relacionado a alguma ação já descrita no diário. Cada ação corresponde a um valor numérico, que pode ser 1,3 e 5.

A tabela 4-8 mostra as sentenças e as notas correspondentes:

Tabela 5-8 Sentenças do "mocinho" e seus valores.

\begin{tabular}{|l|c|}
\hline Sentenças & Nota \\
\hline Receber presentes & 1 \\
\hline Beijar & 3 \\
\hline Apaixonar & 3 \\
\hline (ser/estar) apaixonado & 3 \\
\hline Amar & 5 \\
\hline Dar(flor(es), chocolate(s), jóia(s), presente(s), carta(s), e-mail(s)) & 1 \\
\hline Mandar(flor(es), chocolate(s), jóia(s), presente(s), carta(s), e-mail(s)) & 1 \\
\hline Salvar & 5 \\
\hline Lutar/Vencer & 5 \\
\hline Declarar amor & 5 \\
\hline
\end{tabular}


O personagem masculino com maior número absoluto é o mocinho da narrativa.

\section{Para saber se o mocinho conquista a mocinha}

Depois de decidir quem é mocinho, deve-se buscar quais sentenças do diário estão relacionadas com ele. Cada oração possui uma nota, se o resultado der um número positivo, ele conquistará a mocinha. Se o resultado der um número negativo, ele não conquistará a mocinha. As notas podem ser: $1,-1,3,-3$ ou $5,-5$. A tabela $4-9$ apresenta as orações e respectivas notas:

Tabela 5-9 Sentenças da "conquista" e seus valores.

\begin{tabular}{|l|l|}
\hline \multicolumn{1}{|c|}{ Sentenças } & Valores \\
\hline Amar & 5 \\
\hline Apaixonar & 3 \\
\hline Ser/estar apaixonado & 3 \\
\hline Brigar & -3 \\
\hline Discutir & -3 \\
\hline Trair & -5 \\
\hline Mentir & -3 \\
\hline Contar mentira(s) & -3 \\
\hline Estar, ser feliz & 3 \\
\hline Gostar da mocinha & 3 \\
\hline Ser perdoado & 5 \\
\hline Receber perdão & 5 \\
\hline Ser gentil, educado, companheiro & 1 \\
\hline Declarar amor & 5 \\
\hline Perder confiança, respeito & -3 \\
\hline Ser grosseiro, sem educação, mal educado & -1 \\
\hline
\end{tabular}

As primeiras tabelas servem para decidir quem é o casal principal. Esta descoberta é pré-requisito para responder a questão central: o mocinho conquista o amor da mocinha? Como já foi visto nas tabelas 4-7 e 4-8, 
supõe-se que algumas atitudes são mais importantes que outras para descobrir quem são os personagens centrais. Sendo assim, foram atribuídos os pesos 1, 3 e 5 para as sentenças do diário referentes ao mocinho e à mocinha. Não basta que o nome esteja ligado somente a uma sentença do diário, mas sim que esta sentença tenha um valor maior que a sentença ligada a outra personagem. Isto é importante caso haja um número grande de personagens.

Feito este primeiro filtro, agora o programa deve procurar a resposta para a pergunta central. Neste segundo momento, há uma busca das sentenças do diário no texto digitado, entretanto, como esta pergunta pode ter como resposta tanto que o mocinho conquista o amor da mocinha quanto o mocinho não conquista o amor da mocinha, somente localizar sentenças na narrativa e atribuir valores positivos a elas não será suficiente para buscar a resposta. O diário da "conquista" possui dois tipos de sentença: aquelas que exprimem ações que possam garantir o sucesso do amor do casal e aquelas que exprimem ações que impedem que o amor se concretize. Para sua representação numérica, foram usados números de valores positivos para sentenças favoráveis e números de valores negativos para sentenças desfavoráveis. Desta forma, garante-se um grau de confidência implícito, calculado por uma comparação relativa com as outras entradas de forma a maximizar o valor buscado. Se a soma der um número positivo, a proposição será: (nome do mocinho) conquista amor de (nome da mocinha). Se o valor der negativo, (nome do mocinho) não conquista amor de (nome da mocinha).

\subsubsection{Gênero policial}

Se a narrativa for policial, a pergunta pré-definida característica dele é:

- Quem é o assassino? 
Primeiro é importante descobrir quem é o morto ou quem são os mortos. Depois partir para a busca do assassino(a).

\section{Para descobrir quem é o morto}

Pode-se descobrir o morto só usando a sintaxe. Buscar no campo "sujeito" o nome próprio relacionado a algumas sentenças do diário do gênero policial. A tabela 4-10 mostra a relação entre "sujeito" e a sentençachave:

Tabela 5-10 Sentenças do "morto".

\begin{tabular}{|l|l|}
\hline Sentença & Sujeito \\
\hline Ser (mort, esfaquead,envenenad, ensanguentad) & Nome próprio feminino ou masculino \\
\hline Estar (mort, esfaquead,envenenad, ensanguentad) & Nome próprio feminino ou masculino \\
\hline Morrer & Nome próprio feminino ou masculino \\
\hline Receber tiro & Nome próprio feminino ou masculino \\
\hline
\end{tabular}

Todos os nomes relacionados a tais sentenças são classificados como "morto".

\section{Para descobrir quem é o assassino(a)}

Buscar nos campos "sujeito" e "objeto" nomes próprios relacionados às sentenças do diário. Cada sentença possui um valor 1, 3 ou 5. Que deve ser somado ao final da história. Aquele personagem que possuir maior nota é o assassino. Abaixo a tabela com as sentenças e seus respectivos valores:

Tabela 5-11 Sentenças do "assassino" e seus valores.

\begin{tabular}{|l|l|}
\hline \multicolumn{1}{|c|}{ Sentenças } & Valores \\
\hline Possuir arma; faca; revólver & 1 \\
\hline Saber atirar & 1 \\
\hline Conhecer (química; medicina; biologia) & 1 \\
\hline Saber (química; medicina; biologia) & 1 \\
\hline Pesquisar (química; medicina; biologia) & 1 \\
\hline Cavar & 1 \\
\hline Fazer buraco & 1 \\
\hline Não gostar do morto & 3 \\
\hline $\begin{array}{l}\text { Desejar (herança, esposa, marido, imóvel, imóveis, bens, ações, dinheiro, } \\
\text { fortuna do morto) }\end{array}$ & 3 \\
\hline $\begin{array}{l}\text { Querer (herança, esposa, marido, imóvel, imóveis, bens, ações, dinheiro, } \\
\text { fortuna do morto) }\end{array}$ & 3 \\
\hline
\end{tabular}




\begin{tabular}{|l|l|}
\hline $\begin{array}{l}\text { Ter interesse (herança, esposa, marido, imóvel, imóveis, bens, ações, } \\
\text { dinheiro, fortuna do morto) }\end{array}$ & 3 \\
\hline Odiar morto & 3 \\
\hline Possuir (digitais, arma, copo, faca) & 5 \\
\hline Ter (digitais, arma, copo, faca) & 5 \\
\hline Ser encontrado/a (digitais, arma, copo, faca) & 5 \\
\hline Ser encontrado/a (sangue, mancha de sangue) & 3 \\
\hline Ter encontrado/a (sangue, mancha de sangue) & 3 \\
\hline Possuir (sangue, mancha de sangue) & 3 \\
\hline Amar (mulher do morto, esposa do morto, marido do morto) & 3 \\
\hline Gostar (mulher do morto, esposa do morto, marido do morto) & 3 \\
\hline Atirar & 5 \\
\hline
\end{tabular}

Descobrir o(s) "morto (s)" é mais simples que descobrir quem é o "assassino". Basta localizar o(s) nome (s) do (s) personagens relacionados às sentenças que caracterizam o morto. Já para descobrir o assassino é necessário um critério melhor, pois, há vários suspeitos. Para compor o diário foram escolhidas três tipos de sentenças: as que dizem respeito à habilidade do assassino (sabe atirar, conhece veneno...); as que se referem ao motivo do crime (interesse no patrimônio, no conjugue; ódio...) e as que estão relacionadas à descoberta de uma prova (digitais, marcas de sangue...). Cada sentença possui uma nota que pode ser 1, 3 e 5. Sendo que as sentenças do grupo "habilidade" ganham ponto 1, as do grupo motivo 3 e as da prova 5. As do último grupo ganham a maior nota porque podem ser comprovadas, porém, não basta ter uma prova se não houver um motivo ou mesmo alguma habilidade do assassino. Se acontecer, provavelmente, a prova foi falsificada. Sendo assim, aquele personagem que tiver maior pontuação será o assassino da história.

\subsubsection{Pensamento Paradigmático}

O pensamento paradigmático em "Aristóteles" é representado pelas proposições, ou seja, as respostas dadas às perguntas pré-definidas pelo gênero ao qual pertence à narrativa. A saída do programa vai depender 
então do gênero da história. Neste trabalho, foram feitas duas perguntas básicas:

- Para o gênero romântico: o mocinho conquista a mocinha?

- Para o gênero policial: quem é o assassino?

O formato da resposta será:

- Para o gênero romântico estas são as possíveis respostas:

- "(nome do mocinho) conquista o amor de (nome da mocinha)"; ou

○ "(nome do mocinho) não conquista o amor de (nome da mocinha)"; ou

- "Não foi possível encontrar o mocinho"; ou

- "Não foi possível encontrar a mocinha".

Encontrar o mocinho e a mocinha são pré-requisitos para responder a questão central. Se eles não forem encontrados, isto se deve à falta de dados para a busca.

- Para o gênero policial estas são as possíveis respostas:

- "O assassino é (nome do assassino)"; ou

- "Não foi possível encontrar o assassino".

Esta última sentença resulta da insuficiência de informações para a busca.

Assim, a estrutura da proposição dependerá da pergunta feita. Para este trabalho elas foram suficientes para comprovar como é possível se extrair proposições de narrativas, porém, em uma ampliação do "Aristóteles" poder-se-ia perguntar, por exemplo, "qual(is) motivo(s) levou fulano a cometer o assassinato?" Ou "quais características da mocinha despertaram o amor do mocinho?" E assim por diante.

Esta dissertação argumenta que tais proposições poderiam ajudar na tomada de decisão do observador. Por exemplo, a casa ao lado do observador é alugada por uma pessoa Y. O observador cria uma narrativa em sua mente levando em conta sua vivência, seu conhecimento dos tipos 
de crimes e de atitudes suspeitas (gênero policial). A partir de uma análise da narrativa que o observador acompanha ele pode derivar uma proposição como "X é ladrão". E daí decidir se chama a polícia ou se muda de casa. Outro exemplo, o observador está interessado em X, mas ela está comprometida. Ele cria uma narrativa baseada nos fatos observados, na sua experiência (gênero romântico). Se ele chega a conclusão que $X$ realmente foi conquista por outro, ele pode desistir ou tentar conquistá-la.

\subsection{Trabalhos correlatos}

Não foi encontrado na literatura um trabalho semelhante a este. Entretanto, há alguns que merecem serem mencionados por apresentarem temáticas do mesmo campo desta dissertação. Alguns dos trabalhos desenvolvidos no Cognitio (Poli-USP) se aproximam deste, pelo mesmo campo de pesquisa, Ciência Cognitiva. Já as pesquisas do MIT e da Universidade da Carolina se assemelham por terem como foco de sua pesquisa a criação de narrativas inteligentes. E os games The Sims e Second Life, por criarem narrativas que simulam a vida cotidiana do ser humano.

\subsubsection{Trabalhos do grupo Cognitio}

Dois trabalhos merecem destaque:

- Dissertação de Mestrado de Marcos Antonio Cavalhieri defendida em 2006: Modelo de Comportamento Baseado em Crenças e Teoria de Bayes para Simulações em Vida Artificial - O trabalho reúne características relacionadas aos escopos de pesquisa de Vida e Inteligência Artificial, Ciência Cognitiva, e Realidade Virtual. O objetivo primordial é a concepção de um modelo de comportamento autônomo e adaptativo que permita a interação do personagem virtual num ambiente, mesmo dispondo de informações incertas e vagas. 
Sob esse intuito o projeto desenvolve a conciliação de recursos para tratarem a idéia de racionalizar sobre tais incertezas, promovendo assim, a capacidade de agir assumindo-se alguns riscos decorrentes desse caráter inexato. Por conseqüência, os humanos virtuais são capazes de observar o ambiente no qual se situam, apresentar representações internas e racionalizadas dessas informações incertas, que no trabalho são levantadas como crenças, e ainda tomar decisões baseadas nessas informações. Através do processo de decisão o personagem é capaz de reavaliar as suas crenças; implicando em um comportamento maduro em decorrência dos procedimentos usados para deliberar e realizar ações em um ambiente virtual.

- Tese de Doutorado de Nilton Terra a ser defendida em 2007: Mastermind: Uma Abordagem para Extração de Algoritmos de Raciocínio Lógico Humano - Esta tese em andamento investiga os processos humanos para soluções de problemas a partir do desenvolvimento de um sistema capaz de gerar automaticamente algoritmos para a solução do jogo Mastermind baseado em estratégias apresentadas por jogadores reais. Para isso, utiliza-se o paradigma da programação genética cuja função de avaliação baseia-se em medidas de semelhança entre o algoritmo proposto pelo jogador e os indivíduos de uma população de programas candidatos à solução do problema.

A principal diferença entre estes trabalhos e esta dissertação é o grau de complexidade envolvido. "Aristóteles" usa recursos simples de Inteligência Artificial Simbólica, enquanto o primeiro usa Teoria de Bayes e Vida Artificial e o segundo, programação genética. Mesmo com esta diferença grande, eles se assemelham ao "Aristóteles" em dois aspectos:

- Todos modelos servem para entender como o ser humano toma suas decisões. 
- Todos modelos se baseiam, em maior ou menos grau, em raciocínio lógico.

\subsubsection{Criação de Narrativas Inteligentes: Liquid Narrative Group e Narrative Intelligence}

Michael Young (1999), professor da Universidade da Carolina do Norte e coordenador do Liquid Narrative Group, elaborou o Mimesis, "um sistema de planejamento automático de enredos, com monitoramento de atos falhos". Nos programas desenvolvidos por Young (1999), o plano de ação não é apenas um procedimento para a resolução de problemas, mas serve também para formar um conjunto de potenciais instâncias narrativas. Cria-se uma gama de possibilidades narrativas a serem seguidas dependendo da interação do usuário. No paper Al Based Animation for Interactive Storytelling o pesquisador Marc Cavazza (2001) mostra como as táticas de conquista amorosa de um dos personagens do seriado Friends funcionam dentro do Unreal Tournament, videogame com componentes de inteligência artificial. É criada a seguinte situação, Ross para paquerar Rachel precisa reunir informações antes de tomar a iniciativa e, para isso, tem ao seu alcance algumas opções, como ler o diário dela ou fazer perguntas a uma amiga em comum (Phoebe). No processo de busca, o algoritmo decide qual a melhor seqüência para a ação. Se o jogador esconder o diário de Rachel, planos secundários compatíveis deverão estar disponíveis. O algoritmo desenvolvido Decompositional Partial - Order Causal - Link Planner (DPOCL), desenvolvido por Young (1999), faz com que a história seja decomposta em várias cenas e estágios e preenche os possíveis vazios do plano primário de forma que seja mantida a coerência da narrativa.

O grupo Narrative Intelligence (NI) foi criado em 1990 no Laboratório de Mídia do MIT. Dois estudantes Davis e Travers queriam uma abordagem mais humana da Inteligência Artificial. Eles perceberam o quando a narrativa é fundamental para a compreensão do ser humano depois de terem contato 
com os estudos de Bruner. Eles perceberam que havia um campo muito interessante para ser pesquisado: inteligência narrativa. Ao fundar o grupo, eles se depararam a dificuldade de comunicação entre os teóricos da literatura e os cientistas computacionais. Mateas e Sengers (2002, p. 30):

- Estilo, retórica e interpretação fazem parte do repertório dos teóricos da literatura. E não faz parte da experiência dos cientistas computacionais.

- Lidar com linguagem de programação é rotina para os cientistas da computação e não para os teóricos da literatura.

Com muito esforço estes problemas foram superados e o grupo já tinha uma uniformidade de conceitos. $\mathrm{O} N \mathrm{NI}$ se subdividiu em alguns subgrupos de pesquisa, tais como: Al e Ciência Cognitiva; Teoria Literária; Mídia; Narrativa psicológica e sociológica; Teoria da Interface; Software e Computação Social. Todos os participantes sabiam da atuação de cada grupo e escolhiam um destes campos para se aprofundarem. Todos estavam assim interconectados.

Em 1999 foi feito o primeiro Simpósio de Inteligência Narrativa (MATEAS e SENGERS, 2002, p. 5). Alguns trabalhos merecem ser citados:

- SAGE, Kaleidosteores e Zora: programas em que a criança interage criando narrativas.

- TerminalTime: programa que facilita a criação de documentários a partir de uma "gramática de filmes". Esta é atualizada conforme as histórias são criadas.

De maneira geral, todos os trabalhos apresentados no Simpósio estão afinados com a visão social e cultural que Bruner possui. Todos os artigos tanto os teóricos quanto os que descrevem programas enfatizam a importância da narrativa na sociedade.

Os grupos Liquid Narrative e Narrative Intelligence desenvolvem programas mais robustos que o "Aristóteles. Entretanto, pode-se estabelecer algumas ligações entre eles e o "Aristóteles": 
- Narrative Intelligence se baseou nos estudos de Bruner para desenvolver seus programas;

- Todos estão preocupados em criar narrativas coerentes e verossímeis usando IA;

- Todos consideram a narrativa importante para a compreensão do ser humano.

\subsubsection{Jogos de Simulação do Cotidiano: The Sims e Second Life}

Conforme Curi (2005), The Sims, lançado em 2000, é um jogo em que o usuário pode escolher qual personagem quer ser, homem ou mulher, criança ou idoso, além de poder escolher vários detalhes de seu perfil, como profissão e tipo de vestimenta. Também se pode escolher a personalidade do personagem: simpática ativa, extrovertida, etc. Para Curi $(2005$, p. 2) "O sucesso de vendas foi ainda maior com o lançamento de diversos pacotes de expansão para o jogo original que custam a metade do preço, mas precisam do programa principal (The Sims) para serem executados. Esse tipo de expansão permite que o jogo tenha uma "vida útil" maior antes de ir parar nas prateleiras de promoções". Ainda o mesmo autor critica a comunicação entre os personagens, pois ela é feita através de ícones e não pelo uso da linguagem verbal. Curi (2005) também critica a idéia de realidade/cotidiano; para ele faltam elementos da vida como ideologia e conflitos sociais. De certa forma, o The Sims foi (é) uma evolução no campo de jogos, por ampliar a gama de opções do usuário. A tecnologia empregada serve exatamente para manter o sistema funcionando e garantindo uma narrativa coerente. A figura 4-4 mostra uma cena do cotidiano, amigos se encontram para conversar e paquerar. 


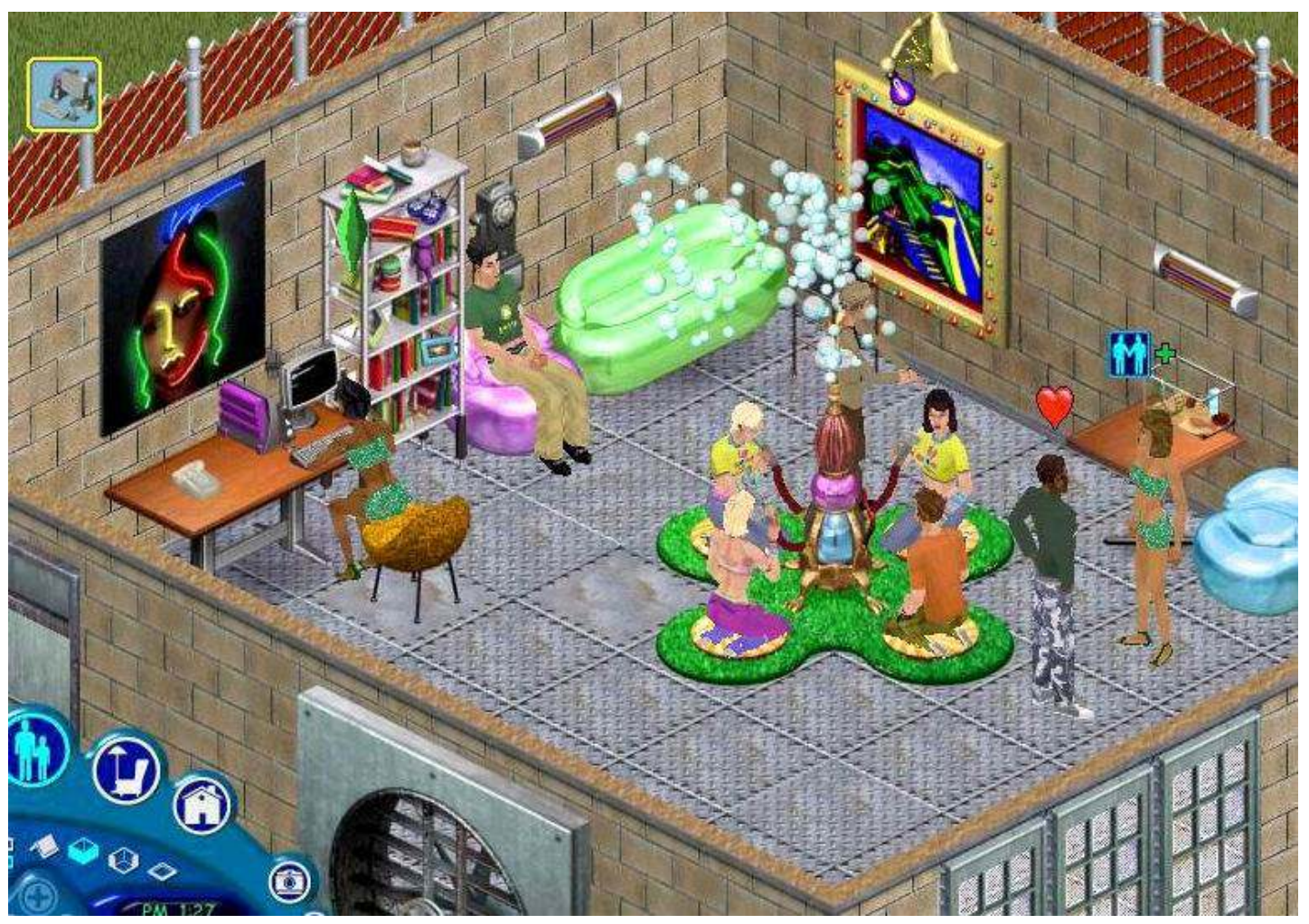

Figura 5-4 Encontro entre amigos "The Sims"

Assis (2005, p.1) considera Second Life "misto de game em realidade virtual com site de relacionamentos”. O jogo como o próprio nome diz, permite que o jogador tenha uma segunda vida, ou seja, ele pode escolher sua nova profissão, um nome, seus amigos, etc. Diferente de The Sims ele é somente jogado via Internet. Para que o personagem consiga interagir em outros lugares, como, festas, ao invés de comprar uma extensão do jogo como fazem os usuários de The Sims, aqui o usuário deve usar um dinheiro virtual adquirido de compras online de terreno virtual ou de salário recebido por uma atividade executada. Como explica Assis (2005): a plataforma tecnológica do mundo paralelo foi desenvolvida em 2003 pela empresa americana Confinem Lab, mas a pequena cidade virtual é configurada pelos residentes. Os ambientes de Second Life são espaços virtuais de três dimensões, que podem ser parecidos com os da realidade ou inventados pelo jogador. A fisionomia dos personagens também é desenvolvida pelo usuário. A tecnologia empregada permite a empresa Confinem Lab consiga 
administrar o que ocorre na cidade. Abaixo a figura 4-5 mostra o jogador voando sobre a cidade. No lado direito da tela, há o mapa para orientar o avatar sobre sua localização.

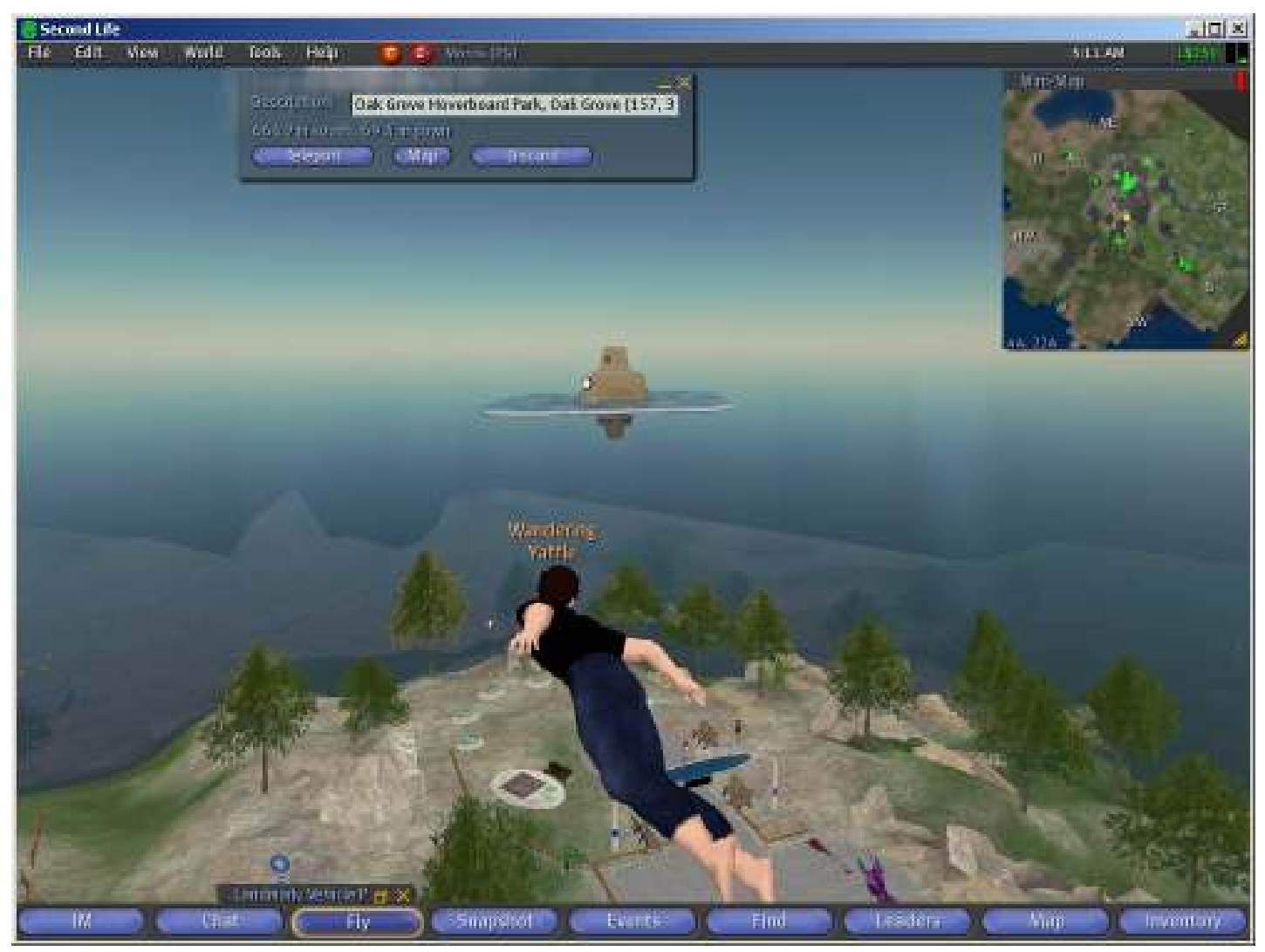

Figura 5-5 Avatar "Second Life"

Estes jogos deram vários passos à frente de jogos de aventura da década de 80 , em que enredo era mais estático e o personagem principal era pré-definido. Tanto em The Sims e Second Life, o jogador representa a si mesmo em algum personagem. Este está amarrado a uma certa classe de narrativas e aquela que realmente é vivenciada pelo jogador depende de tantos fatores, que a torna imprevisível dentro de certos limites a tornando interessante. 
Mesmo sendo mais complexos que o "Aristóteles" e priorizando o entretenimento, estes jogos compartilham com o "Aristóteles" duas características fundamentais:

- Estabelecer uma relação entre narrativa e cotidiano do ser humano;

- Usar estratégias de IA para que as histórias sejam coerentes. 


\section{Testes e Resultados}

Foram testadas 10 narrativas, sendo 5 de cada gênero. São apresentadas 4 narrativas, 2 de cada gênero. Pretende-se, em um futuro próximo, testar os programas com alunos do ensino fundamental. Como já foi dito anteriormente, a narrativa digitada pode ser classificada em 2 gêneros: policial e romântico. Cada gênero possui uma pergunta característica. Para o gênero romântico: "o mocinho conquista o amor da mocinha? Para o gênero policial: "quem é o assassino?". O formato da resposta será:

- Para o gênero romântico estas são as possíveis respostas:

- "(nome do mocinho) conquista o amor de (nome da mocinha)"; ou

○ "(nome do mocinho) não conquista o amor de (nome da mocinha)"; ou

- "Não foi possível encontrar o mocinho"; ou

- "Não foi possível encontrar a mocinha".

- Para o gênero policial estas são as possíveis respostas:

- "O assassino é (nome do assassino)"; ou

- "Não foi possível encontrar o assassino".

Como já foi visto, o formato da resposta depende da pergunta feita. Para esta dissertação foram testadas somente estas duas perguntas e suas respectivas respostas. Como a arquitetura do "Aristóteles" é flexível, é possível adicionar novas classes de gênero apenas instanciando uma classe filha da classe "Gênero".

Em um primeiro momento os testes foram feitos na interface não gráfica e na gráfica, para facilitar a digitação e a verificação do bom funcionamento do programa. No segundo momento, na interface gráfica para avaliar a usabilidade desta: se o usuário digitasse alguma palavra que não 
pertencesse à gramática de entrada, uma caixa de alerta aparecia na tela; se o texto era legível no campo esquerdo da tela; se o contador de gênero estava marcando os valores adequadamente; se os botões exerciam suas funções e se a resposta correta aparecia no campo reservado para ela. Abaixo serão mostradas as narrativas que foram digitadas na interface não gráfica e suas proposições, assim como a interface gráfica para ilustrar como o texto narrativo e as proposições ficam expostos para o usuário. $\mathrm{Na}$ interface não gráfica o "|" representa a separação entre campos sujeito, verbo, objeto 1 e 2, advérbio de tempo e advérbio de espaço.

Foram escolhidas 4 histórias para serem analisadas. A primeira história de cada tipo é mais simples, ou seja, fica evidente a resposta para a pergunta característica. Já a segunda de cada tipo é bem mais estruturada e demonstra claramente como é possível por uma base lógica simples se obter proposições a partir de narrativas.

- História 1

Voltando ao conceito de "narrativa do cotidiano". Imagine que o narrador esteja vendo esta cena abaixo pela janela de sua casa:

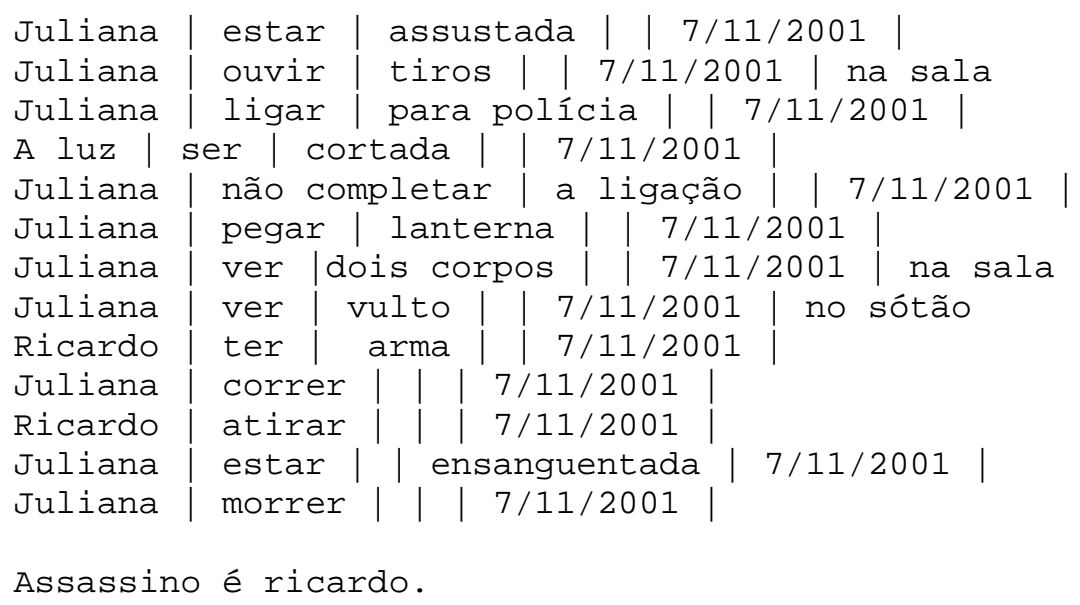

Está evidente que a história é um policial e o assassino é o Ricardo. Neste caso específico, não haveria necessidade da somatória dos pontos das sentenças do diário, porque há somente um suspeito e este cometeu o crime na frente do observador. Porém, o programa não serve para tratar de 
casos específicos, ele deve ser o mais genérico possível para resolver um maior número de casos. Poderia dizer que a história acabou porque o observador não viu mais nada e até aquele momento o assassino é Ricardo. Isto é importante, para perceber que o botão "Fim" não indica o fim da história como acontece na narrativa literária. O "Fim" indica até onde o observador conseguiu registrar a cena, recriando-a mentalmente através do pensamento narrativo.

A Figura 6-1 mostra a interface após o usuário digitar a narrativa. No campo esquerdo, a narrativa e no direito, a proposição. Os contadores de gênero marcam a pontuação conforme o usuário digita a sua história. Ao clicar "Fim", pára a contagem e define que o gênero da história é aquele que possui maior valor, no caso o policial (31). Depois disso, o programa busca a resposta que aprece no campo esquerdo.

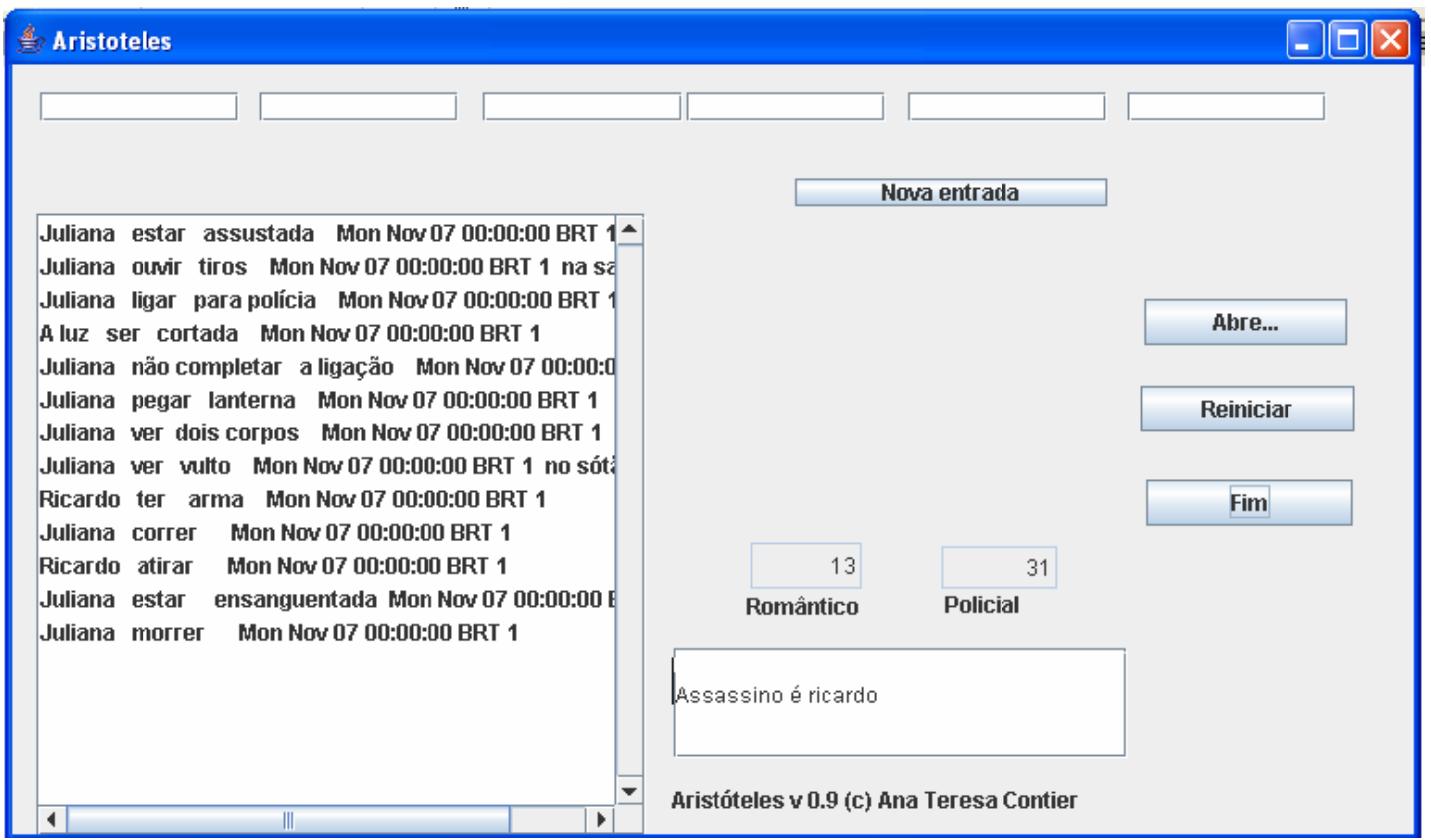

Figura 6-1 Resultado da história 1.

- História 2:

Imagine que o observador tenha conhecido esta história pelos jornais. 


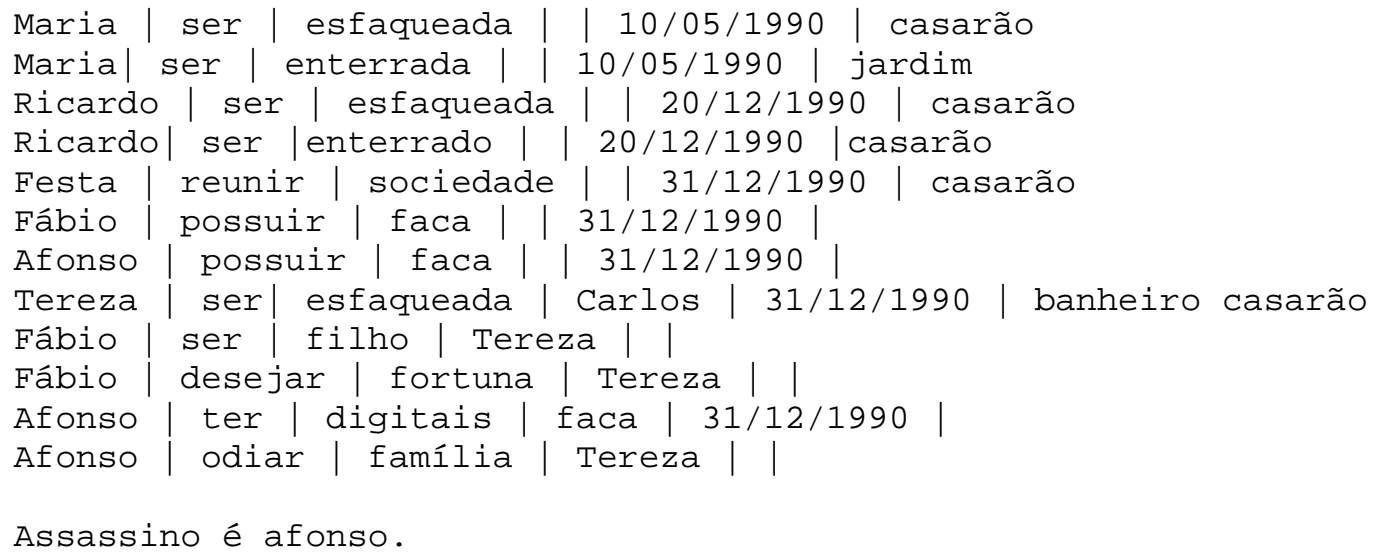

Esta narrativa difere da história 1, pois levanta 2 suspeitos e 3 mortos. Os mortos são Maria, Ricardo e Tereza e os suspeitos, Fábio e Afonso. Neste caso ambos possuem uma faca, ambos possuem motivos, porém somente Afonso tem digitais na faca encontrada. Como foi explicado no capítulo 4, uma prova deste tipo possui uma pontuação maior, já que comprova a autoria do assassinato. Também foi dito que não basta somente encontrar tal prova, porque poderia ser falsa. Nesta história, lembrando que o observado foi até aí, encontrar as digitais de Afonso na faca mais seu ódio pela família de Tereza podem significar que ele seja o assassino. Este resultado vale até o presente momento, talvez se o observador conseguisse mais evidências, Fábio seria o criminoso.

A Figura 6-2 mostra a interface após o usuário digitar a narrativa. No campo esquerdo, a narrativa e no direito, a proposição. Os contadores de gênero marcam a pontuação conforme o usuário digita a sua história. Ao clicar "Fim", pára a contagem e define que o gênero da história é aquele que possui maior valor, no caso o policial (20). Depois disso, o programa busca a resposta que aprece no campo esquerdo. 

Maria ser enterrada Thu May 10 00:00:00 BRT 1990 Ricardo ser esfaqueada Thu Dec 20 00:00:00 BRST Ricardo ser enterrado Thu Dec 20 00:00:00 BRST 19s Festa reunir sociedade Mon Dec 31 00:00:00 BRST Fábio possuir faca Mon Dec 31 00:00:00 BRST 1990 Afonso possuir faca Mon Dec 31 00:00:00 BRST 199 Tereza ser esfaqueada Mon Dec 31 00:00:00 BRST 1 Afonso ter digitais faca Mon Dec 31 00:00:00 BRST

Afonso odiar família Tereza Wed Dec 20 00:00:00 BI
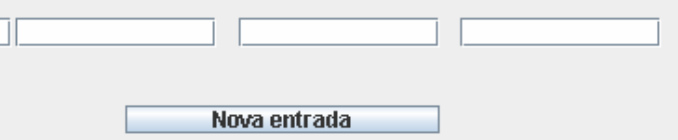

Nova entrada

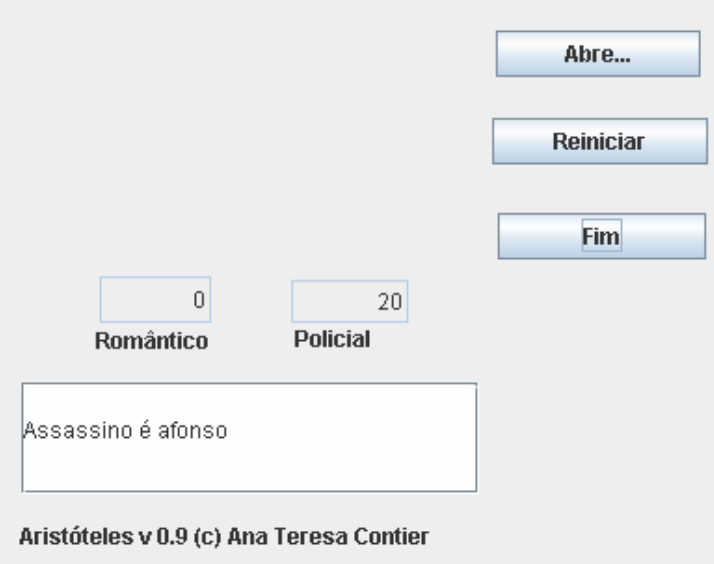

Figura 6-2 Resultado da história 2.

\section{- História 3}

Imagine que o observador tenha ouvido esta história de algum amigo e agora está recriando a situação em sua mente:

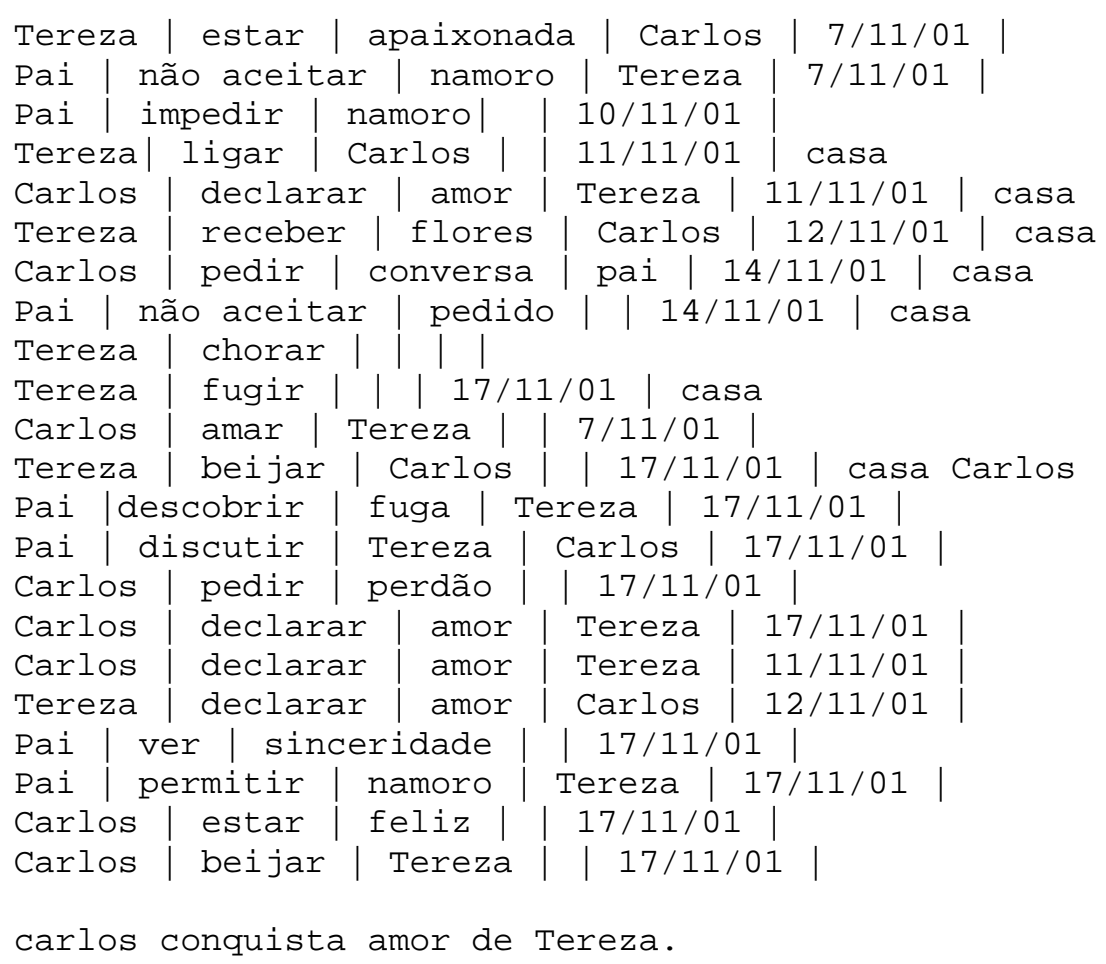


Dos três personagens que compõe a trama, o casal principal é formado por Carlos e Tereza. Mesmo ambos se amando, o pai de Tereza não aceita o relacionamento dos dois, ou seja, para que realmente o amor vença é necessário que Carlos possua atitudes favoráveis e desta forma convença o pai da moça. Nesta história fica claro que Carlos será bem sucedido, já que possui somente sentenças do diário com valores positivos. Porém, este resultado é até o momento. A história pode ganhar outro rumo com acréscimos de fatos negativos. A história 4 mostra como o balanço entre ações favoráveis e desfavoráveis pode resultar em uma proposição negativa.

A Figura 6-3 é a interface gráfica desta narrativa. No campo esquerdo o texto, no direito a proposição. Os contadores de gênero mostram que a narrativa é romântica..

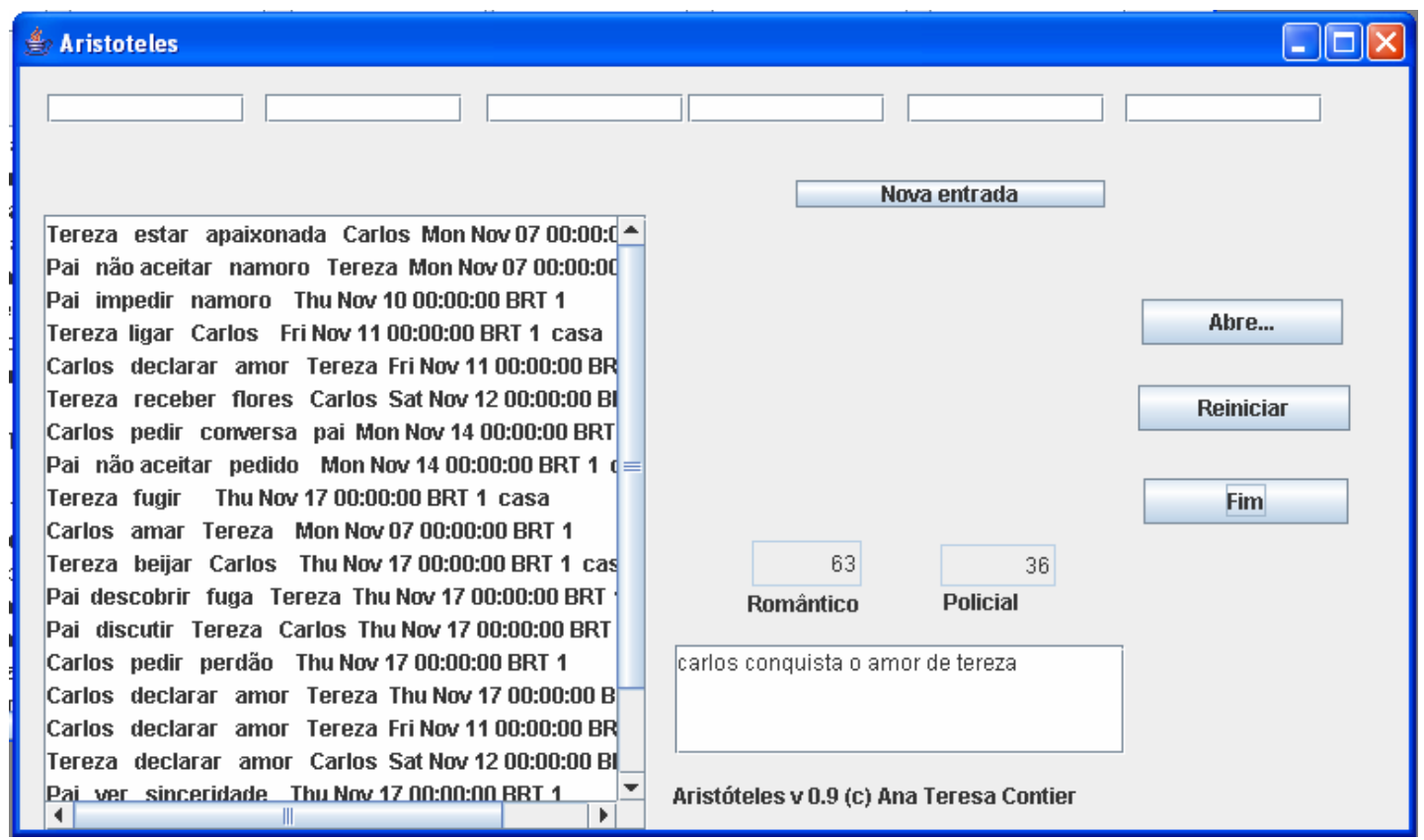

Figura 6-3 Resultado da história 3.

- História 4

Suponha que o observador esteja imaginando o que aconteceu com o amigo dele:

Paula | ser | amiga | Fabiana | 14/10/2000 |

Fabiana | gostar | Caio | | 14/10/2000 | 


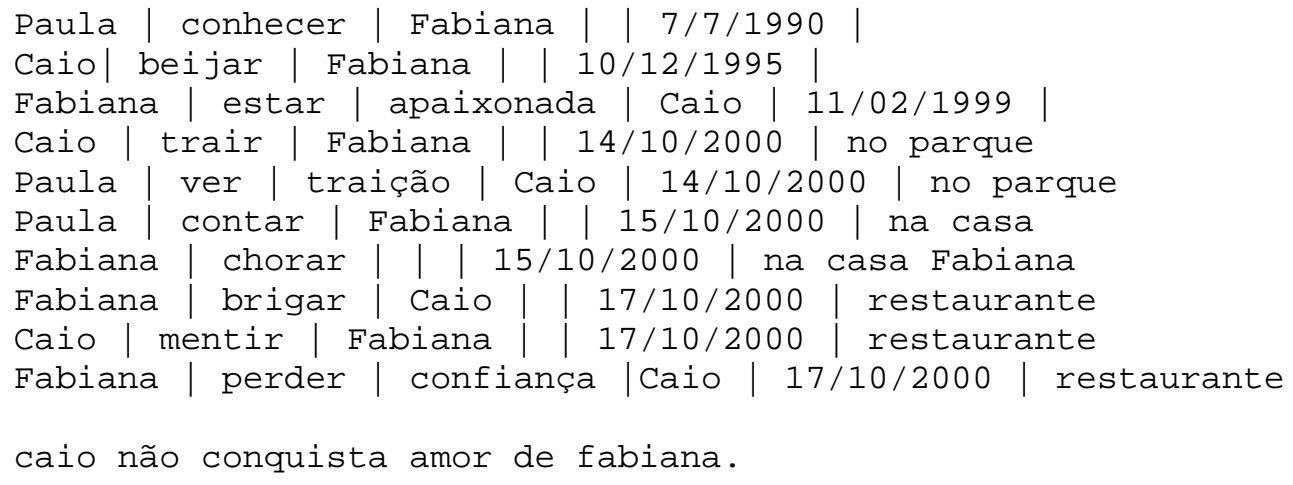

Esta narrativa é um pouco mais complexa que a história 3. Ambas são românticas, só que nesta as atitudes negativas do mocinho fazem com que ele perca o amor da mocinha.

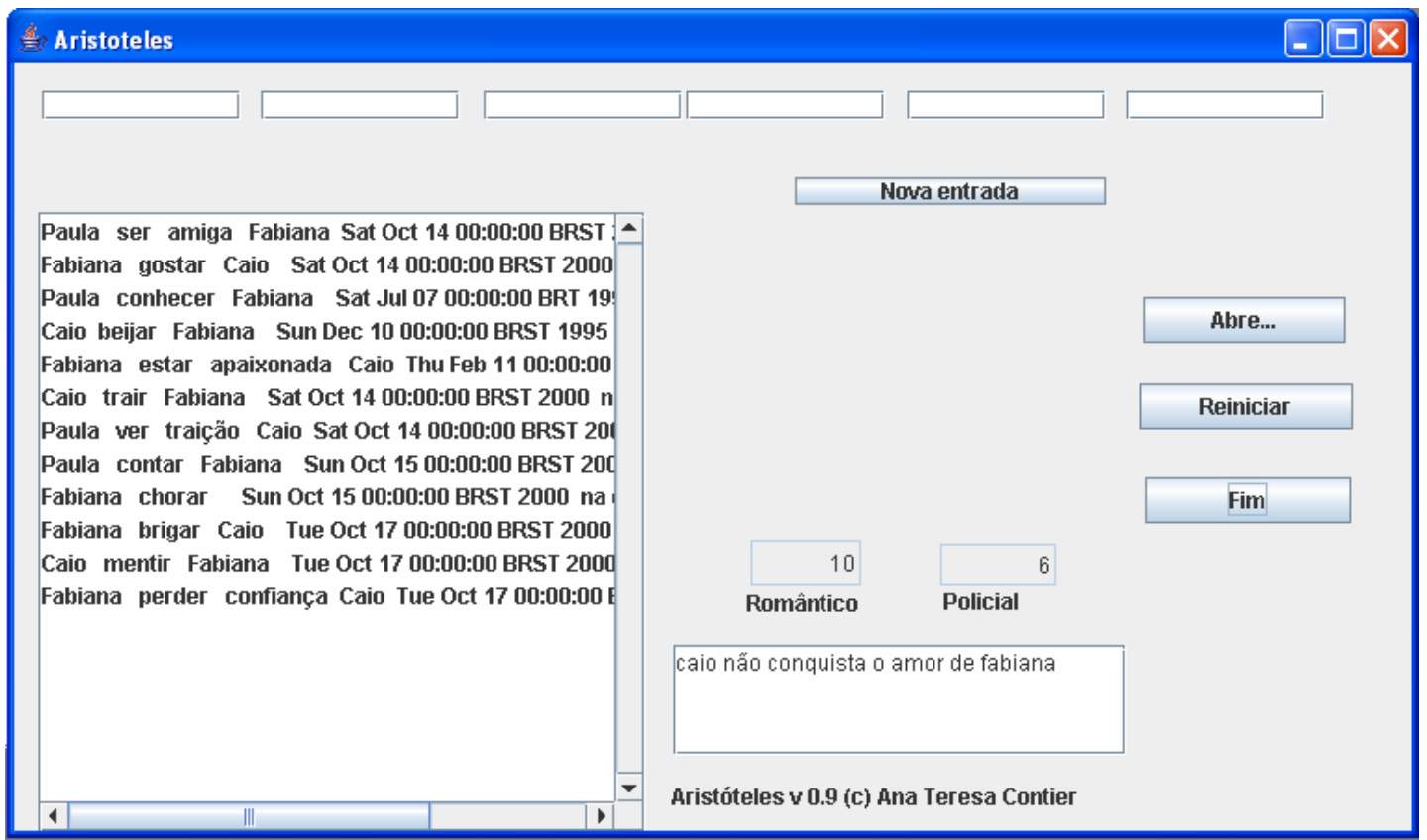

Figura 6-4 Resultado da história 4.

As demais histórias testadas seguem o padrão destas quatro. São textos clichês que seguem a gramática de entrada. Estes resultados demonstram que:

- É possível criar narrativas coerentes a partir de uma gramática de entrada muito simples; 
- A classificação do gênero e as proposições encontradas foram adequadas.

- As informações da interface gráfica estão bem claras, garantindo que o usuário não tenha dificuldade em usá-la.

- Usando uma base lógica muito simples, pode-se extrair proposições a partir de narrativas

Assim, estes resultados comprovam a eficiência do software "Aristóteles" 


\section{Considerações Finais e Trabalhos Futuros}

O estudo da mente é um campo complexo, que exige contribuições de várias áreas, tais como: psicologia, lingüística e computação, entre outras. O pensamento humano é muito rico, e ao longo da história foi muitas vezes visto somente como representação da lógica. Seguindo a concepção racionalista do pensamento, surgiu na década de 50 a Inteligência Artificial Simbólica (IAS). Seu nome decorre da sua principal característica: manipulação de símbolos seguindo regras lógicas. Na mesma época, surgem os primeiros experimentos em Inteligência Artificial Conexionista (IAC), que se apóia nos estudos de neurociência, e em particular em redes formadas a partir de seus elementos mais simples - os neurônios -, que são capazes de perfazer uma série de funções de classificação, e de aprender ao se adaptar às situações a que são submetidos.

$\mathrm{Na}$ década de 80, o psicólogo Jerome Bruner ampliou a questão, dizendo que o pensamento também poderia ser expresso por narrativas, apresentando assim as características das narrativas literárias. O grande problema da teoria deste psicólogo é que ela não chega a ser um modelo científico do pensamento. Isto não invalida sua contribuição para o campo da psicologia, afinal, o autor conseguiu mostrar que o pensamento narrativo é reflexo da cultura e da sociedade. É por meio dele que o homem consegue criar cenários possíveis.

Não se pretendeu nesta dissertação criar um modelo completo do pensamento humano ou mesmo simulá-lo, tarefa certamente complexa, mas sim rever e ampliar certos conceitos relacionados ao pensamento para servirem de base para a construção do software "Aristóteles". Este trabalho possui três objetivos complementares entre si:

- Analisar e ampliar as definições de pensamento paradigmático e narrativo feitas por Bruner na década de 80 ; 
- Mostrar como o pensamento narrativo e o paradigmático atuam de forma conjunta;

- Criar um software em que proposições sejam extraídas de narrativas.

O software "Aristóteles", escrito em linguagem Java, atende a estes objetivos. O usuário digita na interface do "Aristóteles" uma narrativa que segue regras sintáticas pré-definidas. Esta narrativa espelha fatos do cotidiano observados pelo usuário e representa de forma simplificada o pensamento narrativo. A história criada é analisa pela classe gênero. Esta classe funciona como um Sistema Especialista Simbólico adaptado com uma série de regras que vão, primeiramente, classificar a história em gênero romântico ou gênero policial. Feito isto, a narrativa digitada será comparada a um diário com orações-chave características do gênero escolhido. As orações-chave possuem um certo peso, previamente determinado. Assim, quando o sistema encontra tais orações na narrativa apresentada, uma nota é atribuída em função da importância destas orações. Dependendo do resultado, ou é encontrada a resposta para uma pergunta típica de tal gênero ,ou não (quando não se dispõe após tal análise de indícios suficientes, representados pela referida nota) . No caso, foram estabelecidas duas questões:

- Para o gênero romântico: o mocinho conquista a mocinha?

- Para o gênero policial: quem é o assassino?

De acordo com os pesos dados, pode-se chegar as seguintes respostas:

- Para o gênero romântico: "(nome do mocinho) conquista o amor de (nome da mocinha)"; ou "(nome do mocinho) não conquista o amor de (nome da mocinha)", ou "Não foi possível encontrar o mocinho"; ou "Não foi possível encontrar a mocinha". Sendo que estas duas últimas são pré-requisitos para que o programa responda a questão central. Se ele não 
localizar o casal principal não consegue chegar a uma conclusão final.

- Para o gênero policial: "O assassino é (nome do assassino)"; ou "Não foi possível encontrar o assassino". Estas duas últimas sentenças decorrem da insuficiência de informações para a busca.

O pensamento paradigmático é representado pelas proposições, ou seja, as respostas dadas pelo programa. Tais respostas podem orientar a decisão do indivíduo. Por exemplo, uma pessoa que desconfia de seu vizinho, ao colher uma série de evidências e confrontá-las com experiências anteriores (histórias policiais lidas ou vivenciadas), pode concluir que $\mathrm{o}$ suspeito é um assassino e assim chamar a polícia ou fugir. O software não chega a simular qual caminho o indivíduo (narrador) vai escolher, entretanto, abre o caminho para que se discuta que o valor da narrativa não está somente na sua relação com a cultura, mas também na sua integração com o pensamento lógico.

Foram testadas 10 histórias e 4 delas analisadas nesta dissertação. Pode-se perceber pelos resultados que "Aristóteles" conseguiu demonstrar que:

- É possível extrair proposições de narrativas, mesmo usando base lógica de IAS simplificada;

- O uso do "dicionário" e do "diário" com seus respectivos pesos atenderam às expectativas: as narrativas foram corretamente classificadas e suas respostas localizadas;

- A gramática de entrada permitiu a construção de narrativas coerentes;

- A interface gráfica é fácil de ser usada e as informações estão claras para o usuário; 
Portanto, esta dissertação cumpriu os objetivos propostos; fez discussão sobre IA, pensamento narrativo e paradigmático e criou o modelo "Aristóteles" a partir desta análise. Desta forma mostrou como a Ciência Cognitiva pode dar subsídios para a criação de um software, assim como a simulação computacional pode servir de ferramenta para demonstrar uma teoria (várias teorias) sobre a mente humana.

\subsection{Trabalhos Futuros}

O software "Aristóteles", desenvolvido no contexto desta dissertação, cumpre os objetivos propostos, podendo, entretanto, ser ampliado. São sugeridos os seguintes trabalhos para dar continuidade a este:

- Fazer o levantamento de outros gêneros que pertençam ao discurso do cotidiano e sejam expressos em forma de narrativa. E a partir disto estabelecer quais são as questões essenciais a tais gêneros, assim como, o formato das respostas.

- Inserir na classe gênero um sistema de aprendizado para que seja possível a criação de novas regras e/ou exclusão das antigas.

- Permitir que sejam criados pelo próprio sistema subgêneros, ou gêneros híbridos.

- Aceitar períodos compostos; reconhecer as diversas flexões dos verbos; aceitar pronomes do caso reto e oblíquo para garantir que o texto fique mais próximo da Linguagem Natural.

- Construir uma segunda interface em que o usuário possa colocar os pesos para as sentenças ou acrescentar novas sentenças. Outra sugestão seria fazer uma pesquisa com uma quantidade estatisticamente significantiva de pessoas e tirar uma média dos pesos e das sentenças selecionadas. 
- Acrescentar mais dois tipos de sentenças permitidas, ou seja, não seguindo a ordem SUJEITO+VERBO+OBJETOS+TEMPO+LUGAR, tais como, TEMPO+ESPAÇO+SUJEITO+VERBO+OBJETOS; EPAÇO+TEMPO+SUJEITO+VERBO+OBJETOS. Assim, o usuário poderia escolher a forma que mais lhe convém para escrever sua história.

- Adaptar o programa para outras línguas. O software aceitaria sentenças, definiria os gêneros e responderia as questões na língua escolhida pelo usuário. $\mathrm{Na}$ interface gráfica haveria menu no qual ele selecionaria, por exemplo, inglês, espanhol ou português. Para que isso ocorra, deveria ser acrescentado ao dicionário e ao diário palavras e orações destas três línguas.

Enfim, os trabalhos sugeridos complementariam a pesquisa feita e contribuiriam, de certa forma, para o maior entendimento deste particular aspecto da mente humana - a natureza do pensamento humano, suas várias manifestações e relações estabelecidas entre as mesmas. 


\section{Referências}

ASSIS, D. Um mundo paralelo em três dimensões. 2005. Disponível em http://www.link.estadao.com.br/index.cfm?id_conteudo=4773. Acesso em janeiro de 2006.

BAKHTIN, M. Estética da criação verbal. São Paulo: Martins Fontes, 1992.

-.--. Marxismo e filosofia da linguagem. São Paulo: HUCITE/ANNABLUME, 2002.

BITTENCOURT, G. Sistemas Especialistas. 1995. Disponível em www.das.ufsc.br. Acesso em setembro de 2006.

BRUNER, J. Atos de significação. Porto Alegre: Artes Médicas, 1998.

A interpretação narrativa da realidade. In: A cultura da educação. Porto Alegre: Artmed, 2001.

Realidade mental, mundos possíveis. $2^{\text {a }}$ ed. Porto Alegre: Artes Médica, 2002.

CALVIN, W. Evolução do Pensamento. Revista mente e cérebro: Inteligência. São Paulo, Ed Ediouro, n 1, 2004.

CAVALHIERI, M. Modelo comportamental baseado em crenças e teoria Bayesiana para simulações de vida artificial com humanos virtuais. 2006. 97 p. Dissertação (Mestrado). Escola Politécnica. Universidade de São Paulo, 2006.

CARAVAZZA, M- Al-based Animation for Interactive Storytelling. 2001. Disponivel em http://citeseer.ist.psu.edu/542238.htm/. Acesso em junho de 2005.

CHURCHLAND, P. Matéria e Consciência - uma introdução contemporânea à filosofia da mente. Trad. Maria Clara Cescato, São Paulo: Editora UNESP, 1998. 
CURI, F, 2005. Linguagem Digital na Vizinhança Ideal: os limites narrativos do The Sims. In I Seminário Jogos Eletrônicos, Educação Comunicação - construindo novas trilhas, no GT - Jogos Eletrônicos e Narrativas. UNEB, Salvador - Bahia, outubro/2005.

DAZZI, R. Sistemas Especialistas Conexionistas: implementação por redes diretas e bidirecionais. 1999. 135 p. Dissertação (Mestrado). Ciência da Computação. Universidade Federal de Santa Catarina. 1999.

DEL NERO, H. Computação Topológica e controle voluntário em arquiteturas naturais e artificiais. 1997. 254p. Tese (Doutorado). Escola Politécnica, Universidade de São Paulo, 1997.

DUPUY,Jean. Nas Origens das Ciências Cognitivas. São Paulo, Ed. Unesp; 1995.

HELLER, Agnes. O Cotidiano e a História. Rio de Janeiro: Paz e Terra, 1972.

JAKOBSON, R. Lingüística e Comunicação. São Paulo, Ed. Cultrix, 1999.

JOLIVET, R. Curso de Filosofia. Edição Brasileira. Editora Agir. Rio de Janeiro,1972, p.43.

JUNG, C. G. Tipos Psicologicos. Buenos Aires: ed. Sudamericana, 1947, p.542.

KOSIK, Karel. Dialética do Concreto. $5^{\text {a }}$. ed. Rio de Janeito: Paz e Terra, 1989.

LEWIS, H.R.; PAPADIMTTRIOU, C.H. Elements of the theory of computation. Prentice Hall, 1981. 
MATEAS, M e SENGERS, P (org). Narrative Intelligence. Philadelphia, John Benjamins Publishing Company, 2002.

MEYER, M. Folhetim - uma história. São Paulo: Companhia das Letras, 1996.

MUNGIOLI, M. C. P, Narrativas e Computador: diálogos entre mundos reais e mundos possíveis. 2000. 165 p. Dissertação (Mestrado). Faculdade de Educação da Universidade de São Paulo, São Paulo, 2000.

PISTORI, H. Tecnologia Adaptativa em Engenharia de Computação: Estado da Arte e Aplicações. Tese de Doutorado, Escola Politécnica da USP, São Paulo, 2003.

POSNER, M. Cognição. São Paulo: Ed Interameriana, 1980.

POSNER, M (org). Foundations of Cognitive Science. 6a ed. MIT Press, 1998.

QUEIROZ, F. Um Ambiente de Redes Neurais para Web. 1999. Dissertação (Mestrado) Informática. Universidade Federal do Pernambuco, 1999. Disponível em http://www.di.ufpe.br/ tg/19991/fdoq.doc. Acesso em janeiro de 2005, p.14-15.

RIBEIRO, C. Metacognition: a support to the learning process. Psicol. Reflex. Crit, Porto Alegre, v. 16, n. 1, 2003. Disponível em:http://www.scielo.br/scielo.php?script=sci_arttext\&pid=S0102722003000100011\&lng=en\&nrm=iso $>$.Acesso em dezembro 2006)

ROSA, P. Cognição e Tecnologia: Híbridos sob o signo do artifício. Tese (Doutorado). 1996. 200 p. Faculdade de Comunicação. Universidade do Rio de Janeiro. 1996.

RUSSEL S.J; NORVIG. P. Artificial Intelligence: A Modern Approach. Prentice-Hall, 1995. 
TEIXEIRA, J. Mentes e máquinas: Uma introdução à ciência cognitiva. Porto Alegre, RS: Artes Médicas, 1998.

TODOROV, T. Tipologia do Romance Policial. As estruturas narrativas. $4^{\mathrm{a}}$ ed.São Paulo, Ed. Perspectiva, 2004.

TOURETZKY, D; POMERLEAU, D. Reconstructing Physical Symbol System. $1994 . \quad$ Disponível em http://www.cs.cmu.edu/ dst/pubs/simon-reply-www.ps.gz. Acesso em julho de 2005.

VYGOTSKY, L. S. Pensamento e linguagem. São Paulo: Martins Fontes, 1989.

VYGOTSKY, L. S. A formação social da mente. São Paulo: Martins Fontes, 1991.

VYGOTSKY, L. S. e LURIA, A. - Tool and Symbol in Child Development. In René van der Veer e Jaan Valsiner (org.). The Vygotsky Reader. Cambridge, Blackwell, 1994.

YOUNG, M. Models of Narrative for Interactive. 1999 Disponível em http://www.cs.cmu.edu/afs/cs/user/michaelm/www/nidocs/Young.pdf. Acesso em julho de 2005. 